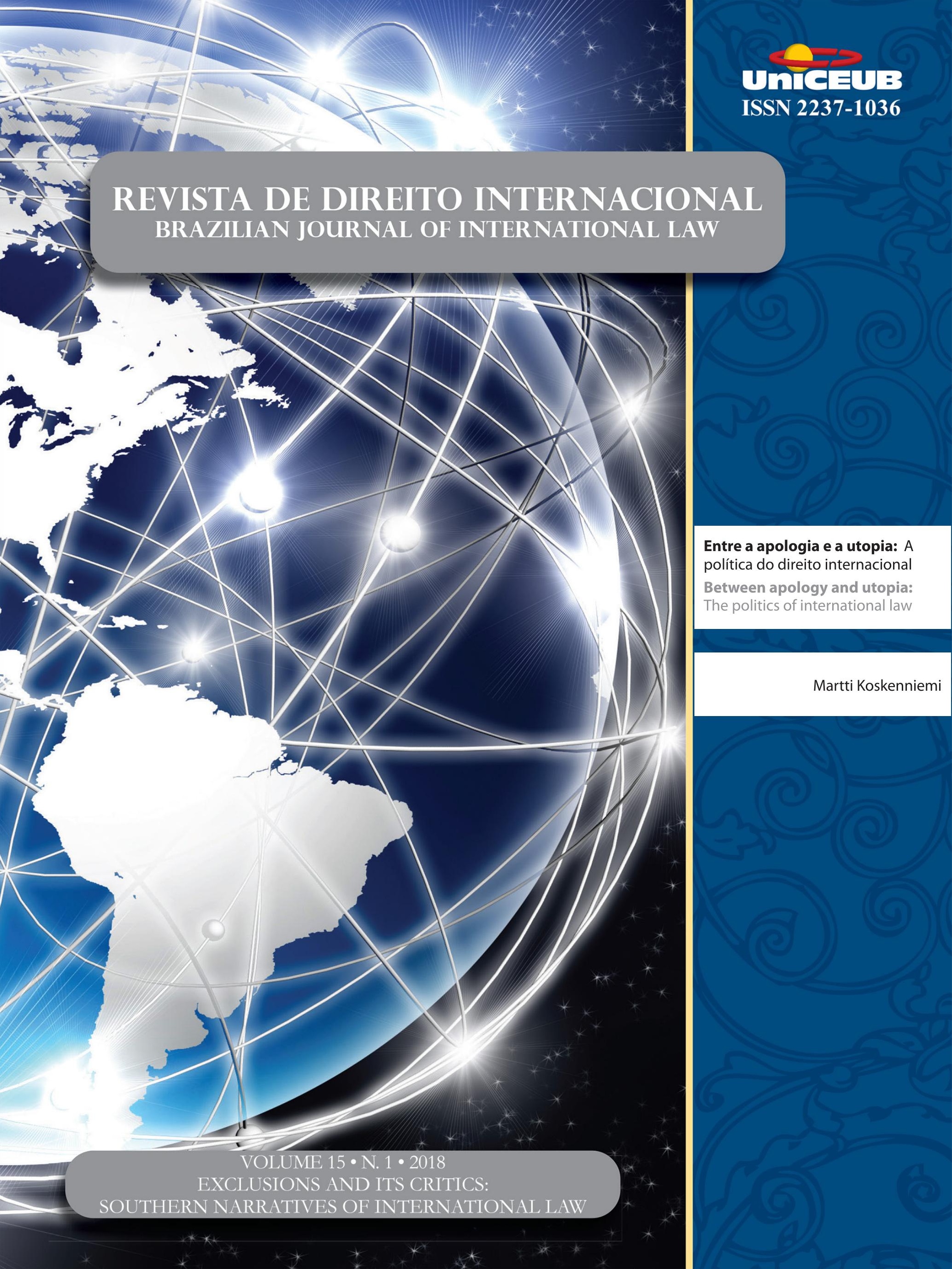




\section{Sumário}

I. Dossiê Especial: Exclusions and its Critics: Southern Narratives of

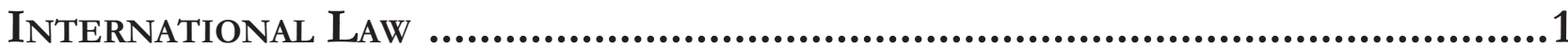

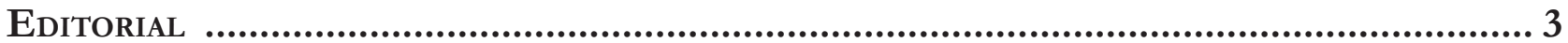

Conseguimos pensar em narrativas críticas do Direito Internacional no Sul Global? ......................... 3

ENTRE A APOLOGIA E A UTOPIA: A POLÍTICA Do DIREITO INTERNACIONAL................................ 6 Martti Koskenniemi e Tradutor João Roriz

A POLÍTICA Do DIREITO INTERNACIONAL: 20 ANOS DEPOIS ...................................................31 Martti Koskenniemi e Tradutor João Roriz

Abordagens terceiro-mundistas para o Direito Internacional: Um Manifesto............42 Bhupinder S. Chimni

Around the pyramid: Political-theoretical challenges to law in the age of global GOVERNANCE

Salem Hikmat Nasser e José Garcez Ghirardi

VOICE AND EXIT: HOW EMERGING POWERS ARE PROMOTING INSTITUTIONAL CHANGES IN THE INTERNATIONAL MONETARY SYSTEM

Camila Villard Duran

LA LIBRE AUTODETERMINACIÓN DE LOS PUEBLOS EN EL SIGLO XXI: UNA APROXIMACIÓN DE LA HISTORIA DEL COLONIALISMO Y EL NEO-COLONIALISMO DESDE LOS PUEBLOS DEL TERCER MUNDO

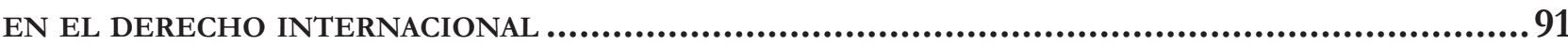

Germán Medardo Sandoval Trigo

INTERNATIONAL CLIMATE CHANGE REGIME AS A PROMOTER OF COLONIAL SYSTEMIC AND SYMBOLIC VIOLENCE: ITS RELATIONSHIP WITH INTERNATIONAL ENVIRONMENT SECURITY AND FOOD SYSTEM THRU THE LENS OF FEMINIST APPROACH 106

Douglas Castro e Bruno Pegorari 
Jus COGENS: AN EUROPEAN CONCEPT? AN EMANCIPATORY CONCEPTUAL REVIEW FROM THE INTER-AMERICAN SYSTEM OF HUMAN RIGHTS

Tatiana de A. F. R. Cardoso Squeff e Marina de Almeida Rosa

O CONHECIMENTO TRADICIONAL RELACIONADO AO COMPLEXO DO CURARE E A LEGISLAÇÃO IN-

TERNACIONAL SOBRE PROPRIEDADE INTELECTUAL. 139

Marcos Vinício Chein Feres e João Vitor de Freitas Moreira

II. Artigos sobre outros temas

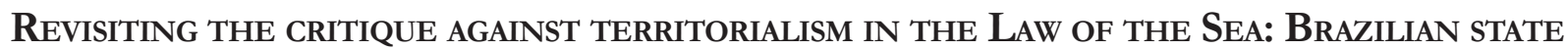
PRACTICE IN LIGHT OF THE CONCEPTS OF CREEPING JURISDICTION AND SPOLIATIVE JURISDICTION ..161 Victor Alencar Mayer Feitosa Ventura

EDUCAÇÃO SUPERIOR INTERCULTURAL, RECONHECIMENTO E REDISTRIBUIÇÃO: O DURO CAMINHO DOS POVOS INDÍGENAS NO EQUADOR 180

Vanessa Wendhausen Cavallazzi, Patrícia Perrone Campos Mello e Raony Soares

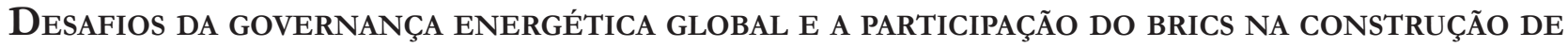
UM NOVO PARADIGMA ENERGÉTICO 200

Fernanda Volpon e Marilda Rosado de Sá Ribeiro

A hermeneutical analysis on the recognition of China as a market economy after 2016.

Alberto Amaral Júnior e Aline Pereira de Carvalho Heringer

THE ISIS ERADICATION OF CHRISTIANS AND YAZIDIS: HUMAN TRAFFICKING, GENOCIDE, AND THE MISSING INTERNATIONAL EFFORTS TO STOP IT

Sarah Myers Raben

The strategic prudence of The Inter-American Court of Human Rights: Rejection OF REQUESTS FOR AN ADVISORY OPINION 255

Cecilia M. Bailliet

Direito Internacional Monocromático: PREVISÃo e apliCaÇÃo dos Direitos LGBTI NA ORDEM INTERNACIONAL 278

Rafael Carrano Lelis e Gabriel Coutinho Galil 
III. RESENHAS

Resenha do livro Empire de Michael Hardt e Antonio Negri 301 Arthur Roberto Capella Giannattasio

Resenha do livro Imperialism, Sovereignty and the Making of International LaW, de

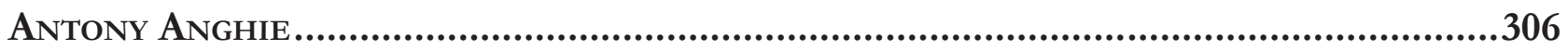

Fabrício José Rodrigues de Lemos e Laura Madrid Sartoretto 


\title{
Entre a apologia e a utopia: A política do direito internacional*
}

\section{Between apology and utopia: The politics of international law}

\author{
Martti Koskenniemi** \\ Tradutor João Roriz***
}

\section{Resumo}

Esta é uma síntese preliminar do estruturalismo abordado em meu livro From Apology to Utopia: The Structure of International Legal Argument ["Da apologia à utopia: a estrutura do argumento jurídico internacional”] (Helsinki, 1989). O texto foi publicado no primeiro número do European Journal of International Law, em 1990, e serve de base para a leitura de todo o meu trabalho posterior. O artigo é inspirado em escritos ligados à tradição dos Estudos Críticos do Direito (Critical Legal Studies) nos Estados Unidos, sobretudo os do professor David Kennedy (Faculdade de Direito de Harvard). Contudo, remete também à linguística estruturalista (Saussure), à teoria da argumentação (Perelman) e ao misto de hermenêutica analítica e teoria crítica que constituiu a ortodoxia da teoria finlandesa do direito nos anos 1980. O objetivo central aqui é mostrar de que modo a indeterminação opera no âmbito da argumentação jurídica internacional. O texto encaminha-se a uma crítica imanente do direito internacional: isto é, a uma crítica pautada em premissas que são elas próprias adotadas pelo discurso profissional do direito internacional. Na medida em que não há fechamento necessário a esse discurso, mas os argumentos prosseguem interminavelmente, qualquer fechamento deve proceder de fora das estruturas do próprio direito, podendo ser caracterizado como uma política do direito internacional.

\section{Abstract}

This is an early summary of the structuralism expounded in my From Apology to Utopia: The Structure of International Legal Argument (Helsinki 1989). It was published in the first issue of the European Journal of International Law 1990 and lays a foundation for the reading of all my later work. The article is inspired by writings in the Critical Legal Studies tradition in the United States, above all by those of Professor David Kennedy (Harvard Law School). However, it also draws upon structural linguistics (Saussure), argument theory (Perelman) and the mélange of analytical hermeneutics and critical theory that formed the orthodoxy in Finnish legal theory in the 1980s. The main point here is to show how indeterminacy works in international legal argument. The article works towards an immanent critique of international law: that is, a critique based on premises that are themselves 
accepted in professional international law discourse. As there is no necessary closure to this discourse, but arguments continue interminably, any closure must come from outside the structures of law itself and such closure may be characterised as a politics of international law.

\section{A fuga da Política}

Estabelecer o advento do sistema moderno de Estados pode configurar uma polêmica razoável entre os historiadores. ${ }^{1}$ Não tão controverso, entretanto, é o fato de que a ideia de tal sistema está histórica e conceitualmente ligada à de um Estado de Direito internacional. Em um sistema cujas unidades em tese não servem a nenhum propósito maior que seus próprios interesses e que pressupõe a perfeita igualdade de tais interesses, o Estado de Direito parece ser, de fato, o único princípio concebível de organização - sem ter que apelar para o bellum omnium. Desde a publicação de Droit des gens ou principes de la loi naturelle appliquées à la conduite et aux affaires des nations et des souverains, de Emerich de Vattel, em 1758, os juristas têm escrito sobre questões internacionais presumindo que os princípios liberais do Iluminismo e seu corolário lógico, o Estado de Direito, poderiam ser aplicados à organização da sociedade internacional assim como o haviam sido na doméstica. ${ }^{2}$

Não obstante a dificuldade histórica envolvendo datas e origens, a conexão entre o Estado de Direito e os princípios do Iluminismo parece evidente. Dentre os princípios iluministas, nenhum parece mais importante

1 Por exemplo, HEYDTE, A. F. Von der. Geburtstunde des souveränen Staates. Regensburg, 1952. p. 41-43, sugere a virada do século XIV, ao passo que HINSLEY, F. H. Power and the Pursuit of Peace. Cambridge: Cambridge University Press, 1962. p. 153. Defende não ser possível falar propriamente de sistema de Estados até o século XVIII

2 A analogia é explícita em ROUSSEAU, J-J. The Social Contract. Harmondsworth: Penguin Books, 1986. p. 63; J. Locke, Two Treatises on Government. p. 183, 211. Para comentários, ver, por exemplo, VINOGRADOFF, P. Historical Types of International Law. Leiden: Brill, 1920. p. 55-57; DICKINSON, E. D. The Equality of States in International Law. Cambridge: Harvard University Press, 1920. p. 2931, 49-50, 97-98, 111-13. Ver também WALZER, M. Just and Unjust Wars. Nova York: Harper and Collins, 1980. p. 58-63; BEITZ, C. Political Theory and International Relations. Princeton: Princeton University Press, 1979.p. 74. Para uma análise profícua acerca do efeito da analogia para a concepção dos direitos (territoriais) de um Estado, ver A. CARTY, A. The Decay of International Law?. Manchester: Manchester University Press, 1986. p. 44-46, 55-56. que o da subjetividade do valor. ${ }^{3}$ Hobbes escreve:

"Pois o que um chama de sabedoria, outro chama
de medo, e um de crueldade, o outro de justiça; e
um de prodigalidade, o outro de magnanimidade...
E eis que tais nomes jamais podem ser estabelecidos
com qualquer raciocinação". ${ }^{4}$

Não importa quanto desagrado as conclusões substanciais de Hobbes ou o seu realismo político tenham causado aos futuros liberais - uma coisa que os une a ele é sua crítica à dependência de princípios naturais para justificar a autoridade política. Apelar para princípios preexistentes à sociedade humana e discerníveis apenas por meio da fé ou da recta ratio significava apelar para máximas abstratas e não verificáveis que somente camuflavam as preferências subjetivas do falante. Tal noção pautava-se em ideais utópicos constantemente usados como apologias à tirania.

Da simples negação da existência de princípios de justiça natural - ou, pelo menos, de nossa capacidade de conhecê-los - decorrem os três princípios liberais da organização social: liberdade, igualdade e Estado de Direito. Se os seres humanos não nascem em um mundo de normas preexistentes, então nascem livres; se inexistem princípios antecedentes que determinariam o valor relativo dos indivíduos, estes devem ser presumidos iguais. Por fim, liberdade e igualdade só podem ser asseguradas se a coerção social for governada por regras públicas, verificáveis e determinantes: "Um povo livre obedece mas não serve; tem magistrados mas não mestres; obedece a nada senão às leis e, graças à força delas, não obedece a outros homens". ${ }^{5}$

A luta por um Estado de Direito internacional é uma luta contra a política, compreendida como instância que promove desejos, paixões e preconceitos subjetivos e que gera a anarquia internacional. Embora certo grau de política seja inevitável (como comumente aceitamos), esta deveria se restringir por regras não políticas: “[...] a saúde da realidade política é mantida pela objeção conscienciosa àquilo que é político". ${ }^{6}$

3 Minha discussão sobre esse princípio é influenciada por UNGER, R. M. Knowledge and Politics. New York: The Free Press, 1975. p. 76-81, e MACLNTYRE, A. After Virtue: a study in moral theory. 2. ed. Notre Dame: University of Notre Dame Press, 1984. p. 6-35. 4 HOBBES, T. Leviathan. Harmondsworth: Penguin Books, 1982. p. $109-110$.

5 J-J. Rousseau, "Oeuvres complètes, Pléiade" (vol. III, p. 842), citado por Cranston (Introduction to Rousseau, The Social Contract (1986), p. 32).

6 WIGHT, M. Western Values in International Relations. In: BUTTERFIELD, W. (Ed.). Diplomatic Investigations: Essays in the 
A história diplomática do século XIX é uma história dessa luta. Desde o Congresso de Viena de 1814-1815 e a derrota de Napoleão, as relações entre as potências europeias deixaram de se pautar pelo esforço de primazia do poder de uma delas e passaram a se orientar por uma busca geral pela manutenção do equilíbrio do poder, assegurado por complexos procedimentos legais e alianças. ${ }^{7} \mathrm{Na}$ medida em que os contemporâneos enxergavam a Europa, cada vez mais, como um "sistema" de comunidades políticas iguais e independentes (em vez de uma respublica Christiana), eles começaram a perceber que os princípios de governança precisavam tornar-se neutros e objetivos - isto é, deviam ser compreendidos como direito.

O saber jurídico do século XIX interpretou e sistematizou a prática diplomática em regras legais. Tal saber concebia o comportamento dos Estados europeus como determinado e explicável por meio da referência a um direito público (europeu). A plausibilidade dessa concepção fundamentava-se na natureza processual desse direito. Ao abranger sobretudo regras referentes a contatos diplomáticos e consulares, bem como procedimentos para a obtenção de soberania, território ou status neutro, este direito público não restringiu severamente os objetivos que os soberanos europeus tentavam alcançar. Particularmente, tal direito renunciou a teorias da guerra justa; a guerra passou a ser um procedimento político dentre outros. ${ }^{8}$ Embora os juristas profissionais do século XIX tenham aludido à justiça no que se refere à conduta dos assuntos dos soberanos, já não a concebiam como um grupo de princípios materiais. Woolsey aborda a questão de forma engenhosa:

\footnotetext{
Por justiça, contudo, buscamos não a justiça objetiva, mas conforme ela aparece para a parte envolvida ou, pelo menos, conforme se supõe que ela exista. Da independência das nações verificase que cada uma tem o direito de manter e fazer cumprir sua própria concepção de direito em seus próprios assuntos. ${ }^{?}$
}

Mesmo que os juristas do século XX não tenham mostrado grande apreciação pela tradição do século an-

Theory of International Politics. Londres: Allen and Unwin, 1966. p. 122.

7 Ver, por exemplo, HINSLEY, F. H. Power and the Pursuit of Peace. Cambridge: Cambridge University Press, 1962. p. 186-271.

8 Ver, por exemplo, WHEATON, H. Elements of International Law. Londres: Clarendon Press, 1936. p. 313-314.

9 WOOLSEY, T. D. Introduction to the Study of International Law: designed as an aid in teaching and in historical studies. 5. ed. Londres: Searle and Rivington, 1879. p. 183. terior, eles nunca rejeitaram o ideal do Estado de Direito. Pelo contrário, a reconstrução da escola de pensamento, que surgiu no início após a catástrofe da Primeira Guerra Mundial e depois nos anos 1950 e 1960, acusou as doutrinas anteriores ao conflito de não terem ido longe o bastante para defender o Estado de Direito. Onde quer que os esforços dos juristas em construir um sólido enquadramento de direito público fracassavam, a causa do problema não residia na falha dos pressupostos liberais subjacentes a esse projeto, mas sim no distanciamento dos juristas em relação a eles.

A noção de um Estado de Direito entre Estados (que ressurgiu, por exemplo, na Resolução 44/23 [15 nov. 1989] da Assembleia Geral da Organização das Nações Unidas, declarando o período 1990-1999 como a "Década do Direito Internacional da ONU") é mais uma reformulação do impulso liberal de fugir da política. A compreensão desta visão é tão forte que o representante da União Soviética, na mesma sessão da Assembleia Geral, explicou que, sob seu ponto de vista, para reestruturar a base das relações internacionais seria necessário "chegar a uma estratégia internacional abrangente que estabelecesse a primazia do direito nas relações entre os Estados". ${ }^{10}$ Com o fim da Guerra Fria, o fortalecimento do Estado de Direito tanto no âmbito nacional quanto internacional integra hoje uma série altamente prestigiada de projetos da ONU. ${ }^{11}$

No decorrer do século XX, as doutrinas reconstrutivas defenderam que é a corrupção do Estado de Direito que merece críticas, seja no chauvinismo restrito dos diplomatas, seja nas utopias especulativas de uma elite acadêmica. Se o Estado de Direito puder ser fortalecido a fim de excluir tais distorções contrastantes, então o papel do jurista na construção de uma ordem mundial justa terá sido cumprido de forma adequada.

Neste artigo, contudo, estenderei a crítica à ideia liberal do Rechtstaat, lugar-comum na sociedade ocidental da modernidade tardia, ${ }^{12}$ ao seu congênere internacio-

10 UNGA, Memorandum: on enhancing the role of international law. UN Doc. A/44/585. 2 out. 1989.

11 Ver, por exemplo, os documentos sobre o Estado de Direito na página da ONU na internet: <www.unrol.org>.

12 Para o restante do texto, particularmente relevantes são as críticas que destacam as tensões internas da teoria liberal. Ver, de modo geral, UNGER, R. M. Knowledge and Politics. New York: The Free Press, 1975. p. 63-103, e, por exemplo, LEVINE, A. Liberal democracy: a critique of its theory. Nova York: Columbia University Press, 1981. p. 16-32 e Fishkin, "Liberal Theory and the Problem of Justification”, NOMOS, XXVD1, p. 207-231. 
nal. Tentarei mostrar que nosso ideal herdado de uma Ordem Mundial pautada no Estado de Direito mascara parcamente o fato de que conflitos sociais devem continuar a serem resolvidos por meios políticos e que, embora possa haver uma retórica jurídica comum entre os juristas internacionais, esta deve, por razões internas ao próprio ideal em questão, apoiar-se em princípios - políticos - essencialmente contestados a fim de justificar os desfechos de disputas internacionais. ${ }^{13}$

\section{O teor do Estado de Direito: concretude E NORMATIVIDADE}

A organização da sociedade por meio de regras legais parte do pressuposto de que tais regras são objetivas no sentido de que ideias, pontos de vista ou preferências políticas não o são. A fim de demonstrar que o direito internacional é objetivo - isto é, independente da política internacional -, a mente jurídica trava uma batalha em duas frentes. De um lado, busca assegurar a concretude do direito ao distanciá-lo das teorias de justiça natural. De outro, busca garantir a normatividade do direito ao criar uma distância entre este e o efetivo comportamento, vontade ou interesse do Estado. O direito somente pode desfrutar de independência da política se ambas essas condições estiverem simultaneamente presentes.

A exigência de concretude resulta do princípio liberal da subjetividade do valor. Para evitar o subjetivismo político e as coerções ilegítimas, ${ }^{14}$ devemos pautar o direito em algo tangível - no comportamento, na vontade e nos interesses reais (verificáveis) dos membros da sociedade - os Estados. A perspectiva moderna endossa uma concepção social de direito. ${ }^{15}$ Segundo ela, o direito não é uma criação natural e sim artificial, um reflexo de circunstâncias sociais. Como tal, seu teor pode ser decifrado de modo imparcial por meio de um estudo atento dessas circunstâncias.

13 Este texto é uma versão resumida de alguns dos temas abordados em KOSKENNIEMI, Martti. From Apology to Utopia. Cambridge: Cambridge University Press, 2005.

14 Para um argumento típico a destacar o caráter político da lei natural, ver, por exemplo, SUR, S. L'interpretation en droit international public. Paris: LGDJ, 1974. p. 25-32, ou VERZIJL, J. H. W. International Law in Historical Perspective. Leiden: Sijthoff, 1968. p. 391-393.

15 C'EST à une conception fonctionnelle de pouvoir, à une conception sociale du droit que s'attache notre enseignement. Recueil des Cours de l'Académie de droit international de la Haye. v. 86, p. 451, 1954. p. 451.
De acordo com a exigência de normatividade, o direito deve ser aplicado independentemente das preferências políticas dos sujeitos jurídicos. Ele não deve apenas espelhar o que os Estados fazem, mas deve manter-se crítico em relação à política estatal. Sobretudo, deve ser aplicável até mesmo contra um Estado que se opõe a tal aplicação. Como os juristas internacionalistas já tiveram oportunidade de destacar, as regras legais cujo conteúdo ou aplicação depende da vontade do sujeito jurídico para o qual são válidas não são regras legais propriamente ditas, e sim apologias ao interesse político desse sujeito. ${ }^{16}$

Nesses termos, creio que se cumprem os requisitos de objetividade legal vis-à-vis subjetividade política. Se o direito puder ser constatado ou justificado apenas com base nas concepções de uma pessoa acerca de como ele deveria ser (isto é, como teorias da justiça), ele coincidiria com as opiniões políticas dessa pessoa. De modo semelhante, se pudéssemos aplicar o direito contra os Estados que o aceitam, então ele coincidiria com as concepções políticas desses Estados.

Tal estrutura argumentativa, porém, que obriga os juristas a provar que o seu direito é válido porque é concreto e normativo no sentido aqui atribuído, tanto cria quanto destrói a si mesma. Isso porque é impossível provar que uma regra, princípio ou doutrina (enfim, um argumento) seja, a um só tempo, concreto e normativo. Os dois requisitos anulam-se entre si. Um argumento referente à concretude trata da proximidade de determinada regra, princípio ou doutrina à prática estatal. Entretanto, quanto mais próximo um argumento estiver dessa prática, menos normativo e mais político ele parecerá, e mais como uma nova apologia acrítica ao poder existente. Um argumento sobre normatividade, em contrapartida, busca demonstrar a distância entre uma regra e a vontade e prática do Estado. Quanto mais normativa (isto é, crítica) for a regra, mais política parecerá porque será menos possível argumentá-la em alusão a um contexto social. Parecerá utópica e - assim como as teorias de justiça natural - facilmente manipulável.

As dinâmicas do argumento jurídico internacional são geradas pelo esforço contínuo dos juristas de demonstrar que o seu direito é concreto ou normativo e pela consequente vulnerabilidade destes à acusação de

16 Ver, por exemplo, LAUTERPACHT, H. The Function of Law in the International Community. Oxford: Clarendon Press, 1933. p. 189 e passim. 
que tal direito é, de fato, político por ser ou apologético ou utópico. Diferentes controvérsias doutrinárias e práticas surgem como transformações desse dilema. Este subjaz dicotomias como "positivismo"/"naturalismo", "consentimento"/“justiça", "autonomia" / "comunidade", "processo"/"regra” etc., e explica por que estas e outras oposições são recorrentes e não parecem passíveis de solução permanente. Elas são recorrentes na medida em que só parece possível defender determinado argumento legal mostrando sua proximidade ou distância da prática estatal. Elas parecem sem solução porque ambas as estratégias argumentativas são vulneráveis ao que parecem ser críticas válidas, compelidas pelo próprio sistema. ${ }^{17}$

Esse processo oferece uma estrutura argumentativa capaz de fornecer uma crítica válida para cada posição fundamental, mas que é, em si, incapaz de justificá-las. O fato de que juristas muitas vezes assumem certas posições e justificam soluções demonstra que a estrutura não possui o tipo de distanciamento da política que o Estado de Direito aparenta postular. Parece possível adotar uma posição apenas por meio de uma escolha política: uma escolha que deve, em última instância, defender-se no sentido de uma concepção de justiça - ou então manter-se substancialmente injustificada. Aceitamos tal escolha porque é assim que agimos.

\section{ESTRUTURAS DOUTRINÁRIAS}

Duas críticas são comumente dirigidas ao direito internacional. Um grupo de críticos o acusa de ser excessivamente político no sentido de depender em demasia do poder político dos Estados. Outro grupo argumenta que ele é excessivamente político por fundamentar-se em utopias especulativas. Questões recorrentes como inexistência de mecanismos legislativos, adjudicação compulsória e procedimentos de execução jurídica englobam ambas as críticas. De um lado, a primeira crítica salienta a infinita flexibilidade do direito internacional, seu caráter de fachada manipulável pela política de poder. De outro, a segunda crítica enfatiza o caráter moralista do direito internacional, seu distanciamento das realidades da política de poder. Segundo a primeira

17 Para um tipo de exposição alternativa, porém semelhante, ver KENNEDY, D. The structure of blackstone's commentaries. Buffalo Law Review, [S.1.], v. 18. p. 205, 1979. crítica, o direito internacional é apologético demais para ser levado a sério na construção da ordem mundial. De acordo com a segunda, ele é utópico demais para o mesmo efeito.

Os juristas internacionalistas têm tido dificuldades em rebater tais críticas. Quanto mais as doutrinas reconstrutivas buscam provar a normatividade do direito, sua autonomia da política, mais elas se tornam vulneráveis ao ataque do utopismo. Quanto maior a insistência dos juristas na íntima conexão entre direito internacional e comportamento estatal, menos normativas suas doutrinas parecem ser. Permita-me delinear as quatro posições adotadas pelos juristas internacionais modernos a fim de provar a relevância de suas normas e doutrinas. Tais posições são mutuamente excludentes e logicamente exaustivas, e esboçam uma explicação integral das possibilidades do argumento doutrinário.

Muitas das doutrinas que surgiram das cinzas da erudição jurídica no fim da Primeira Guerra Mundial explicam o fracasso das doutrinas internacionais pré-guerra no que tange ao seu caráter apologético. Foram alvo especial de crítica as doutrinas "absolutistas" da soberania, expressas sobretudo na Selbstverpflichtungslebre ["teoria da autolimitação"]; doutrinas que destacavam o significado jurídico do equilíbrio do poder ou que delimitavam as funções legais a assuntos sem relação com questões de "honra" ou de "interesse vital". Os escritos de Hersch Lauterpacht, Alfred Verdross e Hans Kelsen, dentre outros autores, estabeleceram uma interpretação altamente influente dos erros das doutrinas do pré-guerra. ${ }^{18}$ Ao associar o fracasso dessas doutrinas à sua proximidade excessiva das políticas de Estado e do interesse nacional e ao defender a autonomia das regras jurídicas internacionais, esses estudiosos abriram caminho para o estabelecimento do que se poderia chamar de abordagem normativa ao direito internacional, salientando assim a normatividade do direito e sua capacidade de oposição à política estatal como a chave para sua relevância restritiva.

Tal abordagem concebe o direito em termos de regras e insiste em um teste objetivo e formal de linhagem (fontes) que revelará quais padrões qualificam como re-

18 LAUTERPACHT, H. The Function of Law in the International Community. Oxford: Clarendon Press, 1933.; VERDROSS, Albert. Die Verfassung der Völkerrechtsgemeinschaft. Viena: Springer, 1926; KELSEN, H. Das problem der sowveränität und die theorie des völkerrechts. Tübingen: Mohr, 1920. 
gras jurídicas e quais não. Se determinada regra passa no teste, então ela é vinculativa. Embora não haja consenso entre os juristas da abordagem normativa sobre o que constitui um teste válido, não há disputa no que se refere à sua importância. As distinções entre direito duro [hard law] e brando [soft law], regras e princípios, normas ordinárias e jus cogens, por exemplo, são suspeitas: elas apenas evidenciam distinções políticas que solapam a objetividade e verificabilidade do direito. ${ }^{19}$ Duas críticas bem conhecidas têm sido dirigidas à abordagem normativa. De acordo com a primeira, essa abordagem permanece incapaz de descartar a influência das considerações políticas de seus supostos testes de linhagem. Admitir que as regras são muitas vezes difíceis de encontrar ao mesmo tempo que seu conteúdo permanece, para empregar a expressão de H. L. A. Hart, "relativamente indeterminado", 20 significa minar a autonomia dessas regras em relação à "avaliação" que a abordagem em questão defende. Conforme a segunda crítica, o próprio desejo de autonomia parece suspeito. Uma teoria pura do direito, a presunção de uma Völkerrechtsgemeinschaft ["comunidade jurídica internacional"] ou o ideal da completude do direito - pressuposto central na maior parte dos estudos sobre a abordagem normativa ${ }^{21}-$ podem simplesmente revelar formas de um utopismo doutrinário irrelevante. Eles obtêm consistência lógica ao custo da aplicabilidade no mundo real da prática estatal.

A segunda posição mais relevante dos estudos contemporâneos usa tais críticas para se consolidar. Uma renomada interpretação continental acerca dos erros de juristas e diplomatas do século XIX concebe-os como resultado de um utopismo ingênuo: uma crença injustificada na viabilidade do sistema do Congresso de Viena, com suas ideias de legalidade e intervenção coletiva. Tal sistema falhou porque não foi capaz de se manter

19 Essa abordagem é mais bem ilustrada em SCHWARZENBERGER, G. The Inductive Approach to International Law. Londres: Stevens; Nova York: Oceana, 1965. Muitos de seus aspectos são discutidos com vigor em WEIL, P. Towards Relative Normativity in International. Law American Journal of International Law, [S.1.], v. 77, p. 413-442, 1983. Para mais referências a essa e outras abordagens, ver KOSKENNIEMI, Martti. From Apology to Utopia. Cambridge: Cambridge University Press, 2005. p. 182-218.

20 HART, H. L. A. The Concept of Law. Oxford: Clarendon, 1961. p. 132.

21 Ver, por exemplo, LAUTERPACHT, Hersch. Some Observations on the Prohibition of 'Non Liquet' and the Completeness of Law. Symbolae Verzijl, [S.1.], p. 196-221, 1958. e a crítica "realista" de STONE. Non-Liquet and the Function of Law in the International Community. The British Yearbook of International Law, [S.l.], v. 25, p. 124-16, 1958. p. 124-161. a par da política do nacionalismo emergente e da crescente rapidez das mudanças sociais e tecnológicas. Juristas como Nicolas Politis ou Georges Scelle destacaram a necessidade de aproximar de modo significativo o direito internacional e as necessidades sociais - e até mesmo biológicas - da vida internacional. ${ }^{22}$ Os textos programáticos de Roscoe Pound serviram de base para a formulação contemporânea dessa abordagem ao criticarem a tentativa de se pensar o direito internacional em termos de regras abstratas. Este deveria ser pensado, em vez disso, "em termos de fins sociais". ${ }^{23}$

Desde o período entreguerras essa abordagem - $a$ abordagem política - tem sido amplamente praticada, em especial nos Estados Unidos, sobretudo sob a influência do realismo jurídico e de seus vários ramos, tais como a "escola processual" ou a "escolha racional". Segundo essa abordagem, o direito internacional somente pode adquirir relevância se estiver firmemente baseado no contexto social da política internacional. As regras são apenas tendências de decisões passadas que podem corresponder ou não a necessidades sociais e instrumentais. Uma "força vinculativa" é uma ilusão jurística. Padrões são, de fato, mais ou menos efetivos e é sua efetividade - sua capacidade de avançar metas sociais - que surge como dado relevante, não sua "validade" formal. ${ }^{24}$

Mas essa abordagem é tão vulnerável a críticas bem fundamentadas quanto a abordagem normativa. Ao enfatizar a concretude do direito, ela irá, em última análise, descartar completamente sua força restritiva. Se o direito é apenas aquilo que é efetivo, então, por definição, ele se torna uma apologia aos interesses dos poderosos. Se, na esteira de Myres McDougal, tal consequência for evitada por meio da formulação de certos "valores de metas" cuja importância jurídica independe de considerações de efetividade, então a abordagem política (revisada) passa a ser vulnerável às críticas que ela inicial-

22 SCELLE, G. Précis de droit des gens: Principes et systématique I-II. Paris: Sirey, 1932.; POLITIS, N. Les nowvelles tendances du droit international. Paris: Hachette, 1927.

23 POUND, R. Philosophical Theory and International Law. Bibliotheca Visseiana, [S.1.], v. 1, p. 1-90, 1923. p. 1-90.

24 Para uma formulação bastante conhecida, ver MCDOUGAL, M. S. International law, power and policy: a contemporary perspective. Recueil des Cours de l'Académie de droit international de la Haye, [S.1.], v. 82, p. 133-259, 1953. Para uma análise produtiva, ver ROSENTHAL, B. L'étude de l'auvre de Myres Smith McDougal en matièredu droit international public. Paris: LGDJ, 1970. Ver também os ensaios de Wiessner e Millard e de O'Connell e Abbott em S. R. Ratner e A-M. Slaughter, The Methods of International Law (Washington DC, ASIL, 2004). 
mente expressou em relação à abordagem normativa. De modo específico, ela parece assumir um naturalismo ilegítimo que - como os críticos que destacam o princípio liberal da subjetividade do valor têm observado - está em constante risco de se tornar apenas uma apologia às políticas de certos Estados. ${ }^{25}$

A abordagem normativa e a política são duas formas distintas de tentar estabelecer a relevância do direito internacional em face do que parecem ser críticas bem fundadas. A primeira busca salientar a normatividade do direito, mas não consegue ser convincente em razão da falta de concretude. A segunda baseia-se na concretude do direito internacional, mas perde a normatividade, a força crítica desse direito. Não surpreende, pois, que alguns juristas tenham assumido as duas posições restantes: ou pressupõem que o direito internacional não possa ser entendido como normativamente controlador nem amplamente posto em prática (posição cética), ou continuam produzindo estudos como se tanto a força vinculativa do direito quanto sua correspondência com os desenvolvimentos da prática internacional fossem uma questão de direção (posição idealista). A primeira termina em cinismo, a segunda em contradição. ${ }^{26} \mathrm{~A}$ tradição da modernidade tardia muitas vezes se situa entre as abordagens normativa e política. Nas palavras de Richard Falk, a tarefa atual de uma doutrina adequada é fixar "[u]ma posição intermediária, que preserve o caráter distintivo da ordem jurídica ao mesmo tempo que tente demonstrar capacidade de resposta diante da criação extralegal da política, da história e da moralidade". ${ }^{27}$

Mas tal movimento rumo ao ecletismo pragmático parece ser autodestrutivo. Não há espaço entre as quatro posições, a abordagem normativa, a abordagem política, o ceticismo e o idealismo. As doutrinas moderadas somente aparentam ter credibilidade na medida em que seus argumentos, doutrinas ou normas não são

25 Para tal crítica, ver, por exemplo, ALLOTT, P. Language, Method and the Nature of International Law. The British Yearbook of International Law, [S.1.], v. 45, p. 123-125, 1971. p. 123-125; BOYLE, Ideals and Things: International Legal Scholarship and the PrisonHouse of Language. Harvard Journal of International Law, [S.l.], v. 26, 1985.; FITZMAURICE, G. Vae Victis or Woe to the Negotiators! American Journal of International Law, [S.1.], v. 65, p. 370-373, 1971.

26 A título de referência, ver KOSKENNIEMI, M. From Apology to Utopia: the structure of international legal argument. Cambridge: Cambridge University Press, 2005. p. 197-200, 209-218.

27 FALK, R. The Interplay of Westphalia and Charter Conceptions of the International Legal Order. In: FALK, R.; BLACK, C. (Ed.). The Future of the International Legal Order. Princeton: Princeton University Press, 1969. p. 34-35. alvo de contestação. Mas assim que a discordância vem à tona, elas também devem defender suas posições, seja revelando sua força vinculativa autônoma, seja demonstrando sua íntima relação com aquilo que os Estados efetivamente praticam. Nesse ponto, tornam-se vulneráveis à acusação de serem utópicas ou apologéticas.

O resultado é uma estrutura doutrinária curiosamente incoerente em que cada posição é ad hoc e, portanto, apenas sobrevive. A doutrina mainstream recolhe-se a afirmações gerais sobre a necessidade de "combinar" concretude e normatividade, realismo e idealismo, as quais não têm efeito sobre sua conclusão normativa. Ela segue adiante, destacando a contextualidade de cada solução - assim solapando sua própria ênfase no caráter geral e imparcial de seu sistema.

As contradições do direito internacional levam-no forçosamente a um pragmatismo empobrecido e irreflexivo. Por um lado, preserva-se a ilusão "idealista" de que o direito pode e de fato desempenha um papel na organização da vida social entre os Estados. Por outro, as críticas "realistas" são aceitas e o direito é visto como claramente secundário ao poder e à política. A doutrina moderna, como mostra Philip Allott, adota um misto de argumentos positivistas e naturalistas, consensualistas e não consensualistas, teleológicos, práticos, políticos, lógicos e factuais numa alegre confusão, alheia às suas contradições internas. ${ }^{28} \mathrm{O}$ estilo sobrevive porque reconhecemos nele a doutrina liberal no âmbito da qual estamos acostumados a expor, de forma veemente, nossos argumentos políticos.

Uma última questão deve ser abordada. Cada uma das posições elencadas, assim como suas combinações, permanece distintamente moderna. Cada uma delas se recusa a desenvolver seu conceito de direito com base em uma teoria material da justiça. Cada uma entende que o direito é uma criação humana artificial que surge por meio de processos sociais, e que um conceito adequado de direito é aquele apto a fornecer uma descrição confiável de tais processos e seus efeitos. Ademais, cada uma constrói sua pretensão à superioridade perante a outra com base nessa mesma descrição. O ponto em que divergem diz respeito à sua teoria sobre como interpretar tais processos, como entender o que acontece na vida social em termos de criação e aplicação de leis.

28 ALLOTT, P. Language, Method and the Nature of International Law. The British Yearbook of International Law, [S.l.], v. 45, p. 123-125, 1971. p. 100-105, 113. 
A dificuldade em optar pela abordagem normativa ou pela abordagem política corresponde à dificuldade em defender o conjunto de critérios que elas promovem a fim de separar o "direito" de outros aspectos do comportamento estatal. Para o jurista da abordagem normativa, os critérios relevantes são fornecidos por sua teoria das fontes. Para o jurista da abordagem política, os critérios correspondentes são fornecidos por sua teoria dos "valores primários", autoridade ou por alguma espécie de constelação de interesses e necessidades nacionais ou globais. Uma vez que tais critérios alegam oferecer a descrição correta dos processos sociais, não é possível defendê-los sem a circularidade dos próprios processos sociais. ${ }^{29} \mathrm{~A}$ fim de selecionar a melhor abordagem, seria preciso pautar-se em determinada teoria não descritiva (não social) sobre significados ou sobre a justiça relativa dos tipos de direito disponibilizados pelas duas - ou por quaisquer outras - matrizes. ${ }^{30}$ Tal decisão, segundo a concepção social do direito e o princípio da subjetividade do valor, não teria, para todos os efeitos, qualquer tipo de pretensão à correção objetiva. Seria, pois, uma decisão política.

\section{Estruturas SUbStancials}

É possível delinear a tensão entre as demandas de normatividade e concretude por meio de dois métodos contrastantes que explicam a origem da substância do direito. Do ponto de vista da concretude, essa substância surge como consequência do fato da soberania de um Estado. Um aspecto da soberania é a liberdade de "legislar" normas internacionais vinculativas a si mesmo. Em todo e qualquer lugar onde normas específicas não tenham sido assim estabelecidas, o metaprincípio

29 A questão sobre matrizes conceituais, teorias científicas, "paradigmas", interesses de conhecimento ou preconceitos, se não determina estritamente aquilo que podemos saber a respeito de nosso mundo social, pelo menos influencia nossa percepção de forma significativa, constitui um tema comum em boa parte da epistemologia moderna. Para mais sobre esse tema, ver KOSKENNIEMI, M. From Apology to Utopia: the structure of international legal argument. Cambridge: Cambridge University Press, 2005. p. 522-532.

30 Em se tratando da escolha de traços significativos para descrição, ver, por exemplo, J FINNIS, J. Natural Law and Natural Rights. Nova York: Clarendon Press, 1980. p. 3, 9-18. Ver também MACINTYRE, A. The Indispensability of Political Theory. In: MILLER, D.; SIEDENTOP, L. (Ed.) The Nature of Political Theory. New York: Clarendon Press, 1983. p. 19-33. da liberdade soberana - o "princípio Lótus" - permanece válido.

É igualmente possível compreender o direito como consequência do funcionamento de critérios normativos para o surgimento de um corpo jurídico. Do ponto de vista da normatividade, são necessários supostos critérios - "fontes" - que nos permitam distinguir entre o fato da existência e do comportamento de determinados centros de poder (Estados) e o direito. Nesse sentido, toda substância jurídica internacional depende do conteúdo de tais critérios. Essas explicações parecem radicalmente conflitantes e em tese fornecem métodos exaustivos, porém incompatíveis, para a elucidação da origem e natureza do direito internacional. De fato, boa parte da disputa entre "idealistas" e "realistas", ou entre as abordagens normativa e política, parece engolfada por esse contraste, expresso também na organização da substância de manuais convencionais. Uma opção estilística consiste em preceder a substância do direito com uma análise do caráter da estatalidade e da ordem internacional - as "bases políticas". Uma outra começa por listar as fontes do direito internacional e permite que a substância do direito prossiga a partir daí.

A despeito de suas perspectivas inicialmente opostas, ambos os "métodos" dependem um do outro. As doutrinas "realistas" adotam critérios para distinguir entre direito e coerção que não se enquadram em uma doutrina das fontes apenas por não receberem essa designação. Os programas "idealistas”, por sua vez, acabam por indicar a prática estatal a fim de defender a relevância de suas fontes e verificar o conteúdo do direito que apoiam. ${ }^{31} \mathrm{O}$ fato de que as perspectivas disponíveis fornecem sistemas substanciais idênticos e de que ambos se mantêm vulneráveis a críticas bem ensaiadas corrobora ainda mais o tardio giro moderno em direção ao pragmatismo doutrinário.

No âmbito da prática internacional de resolução de disputas, a falta de uma explicação satisfatória para a origem das regras legais tem levado os juristas a abandonar a busca por justificativas para a resolução de controvérsias interpretativas em quaisquer das explicações sugeridas. Por trás de referências ritualísticas a regras e princípios conhecidos do direito internacional (o conteúdo dos quais permanece alvo de disputas frequentes), a prática jurídica tem apelado cada vez mais para

31 Comparar também Kennedy, International Legal Structures (1987). 
a resolução de disputas por meio de um critério contextual - um esforço voltado para um equilíbrio equitativo. Embora tal estratégia pareça ser bem-sucedida, é preciso questionar se ela pode ser explicada de forma satisfatória em termos do Estado de Direito.

\subsection{Soberania}

Há um corpo doutrinário que trata da seguinte questão: quais são o caráter e as consequências normativas da soberania? Ele lida com temas como a aquisição e perda da estatalidade, a justificação e extensão (limites) da soberania territorial, os direitos dos Estados, a delimitação de jurisdições concorrentes, etc. A importância retórica dessa doutrina tem oscilado, mas sua urgência no contexto da doutrina liberal mantém-se incontestável. De certa forma, a doutrina da soberania exerce um papel análogo ao da liberdade individual no discurso de legitimação doméstica. Ela explica o que significa ser um sujeito de direito e em seguida estabelece as condições básicas em meio às quais as relações entre os sujeitos devem ser organizadas.

A natureza e as consequências da estatalidade soberania podem, contudo, ser abordadas a partir de perspectivas diferentes. Uma interpretação considera a soberania como básica no sentido de ser simplesmente imposta ao direito pelo mundo dos fatos. A soberania e, com ela, um conjunto de direitos e deveres territoriais são de algum modo exteriores ao direito, algo que este deve reconhecer mas não pode controlar. Chamarei esse fenômeno de "perspectiva do fato puro". ${ }^{32}$ Outra interpretação considera a soberania e tudo o mais associado a ela como parte da substância do direito, determinados e constantemente determináveis no âmbito do sistema legal, como qualquer outra norma. Esta poderia ser chamada de "perspectiva jurídica". ${ }^{33}$

$\mathrm{O}$ argumento normativo nos diversos domínios da doutrina da soberania adota a divergência entre essas interpretações para constituir-se a si próprio. Uma de-

32 JELLINEK, G. Allgemeine Staatslehre. Berlim: Haring, 1925. p. 337, 364-367, e, por exemplo, KOROWICZ, M. Some Present Problems of Sovereignty. Recueil des Cours de l'Académie de droit international de la Haye, p. 102, 1961.

33 Ver, por exemplo, VERDROSS, Albert. Die Verfassung der Völkerrechtsgemeinschaft. Viena: Springer, 1926. p. 35, e, por exemplo, ROUSSEAU, C. Principes de droit international public. Recueil des Cours de l'Académie de droit international de la Haye, [S.1.], v. 93, p. 394, 1958. p. 394 las elabora sua argumentação em termos de fatos puros (de efetividade, por exemplo), enquanto a outra defende seu ponto de vista recorrendo a um critério exterior aos fatos (reconhecimento geral, por exemplo). Contudo, nenhuma delas é sustentável por si só. Apoiar-se no fato puro do poder é apologético. ${ }^{34}$ Apoiar-se em um critério independente de efetividade é ao mesmo tempo abstrato e uma "petição de princípio"35. ${ }^{36}$ Trata-se de uma petição de princípio porque ela meramente levanta a questão adicional sobre qual interpretação do critério ou de sua aplicação deveria ser priorizada. Um argumento defensável parece compelido a abranger ambas questões: deve pressupor que os direitos de soberania são, de alguma forma, assuntos de fatos puros assim como de algum critério exterior aos próprios fatos.

O desenvolvimento dos posicionamentos da Noruega e da Dinamarca durante o caso da Groenlândia Oriental (1933) ilustra essa questão. De início, a Noruega pautava seus direitos ao território disputado na sua efetiva ocupação. Recorrer aos pontos de vista de outros Estados teria violado a igualdade soberana da Noruega. A Dinamarca fundamentava sua alegação no reconhecimento geral e desafiou o título norueguês diante da ausência desse reconhecimento. Uma vez que o título teria validade erga omnes, ele não poderia depender dos atos da Noruega. Em seus argumentos posteriores, ambos os Estados assumiram a primeira posição do adversário: a Noruega argumentou que sua ocupação era sancionada por uma regra amplamente reconhecida que chancelava títulos com base na ocupação, ao passo que a Dinamarca buscou mostrar que a Noruega, de fato, não poderia ter ocupado o território porque este já havia sido efetivamente ocupado por ela. ${ }^{37}$

Não seria possível eleger nenhuma das reivindicações com base na simples preferência por "fato puro" ou pelo "critério" de reconhecimento geral porque am-

34 Ver, por exemplo, LAUTERPACHT, H. International Law. Cambridge: Cambridge University Press, 1979. p. 341-344.

35 O autor usa a expressão "question-begging" que indica uma retórica falaciosa na qual se afirma uma tese na conclusão, mas que tem tal conclusão como premissa. Optou-se pela expressão "petição de princípio", mais próxima da sua versão original em latim, petitio principii (N.T.).

36 Ver, por exemplo, Island of Palmas Case. Reports of International Arbitral Awards, vol. 2, p. 839, 843-846.

37 Tais questões são discutidas em pormenor nos anais escritos. Ver o caso "Eastern Greenland", PCIJ Rep Series C n. 62 e C n. 63, além da argumentação oral das partes em $\mathrm{C}$ n. 66. Para uma análise mais detalhada, ver KOSKENNIEMI, Martti. From Apology to Utopia. Cambridge: Cambridge University Press, 2005. p. 288-293. 
bos os Estados utilizaram os dois argumentos. Consequentemente, a Corte validou os dois cursos argumentativos. Para corroborar sua visão de que a Dinamarca possuía soberania, ela pautou sua argumentação tanto na ocupação dinamarquesa quanto no reconhecimento geral e negou ambos em relação à Noruega. ${ }^{38} \mathrm{~A}$ fim de chegar a essa conclusão, a Corte teve que elaborar interpretações sobre os fatos (ocupação efetiva) e o direito (o alcance do reconhecimento geral) que, entretanto, eram exteriores aos fatos aplicáveis e ao direito e de difícil justificativa diante da interpretação soberana conflitante da Noruega em relação a elas. O ponto crucial do julgamento foi o debate em torno da notória "declaração de Ihlen”, que permitiu à Corte proteger a soberania norueguesa ao negar sua posse, aludindo à formulação segundo a qual a Noruega já havia "reconhecido" a soberania dinamarquesa na Groenlândia Oriental. ${ }^{39}$

A mesma estrutura pode ser detectada em todas as disputas territoriais. Nestas, as abordagens do "fato puro" e "jurídica" dissolvem-se uma na outra de forma a tornar impossível para a corte ou tribunal resolver o caso por meio da simples escolha de uma ou de outra. Há dois entraves. Primeiro, a necessidade de endossar ambas as perspectivas perde o sentido inicial delas: a perspectiva do fato puro baseia-se no pressuposto de que o direito sucede ao que os fatos dizem. Por sua vez, a perspectiva jurídica entende que as regras deveriam determinar o sentido dos fatos. Em princípio, ambas as visões alegam protelar ou sobrepor-se à outra. Pressupor que poderiam ser simultaneamente válidas (determinantes) torna-as desprovidas de sentido. Segundo, uma vez que as abordagens em questão se mostram indeterminadas, o tomador de decisão é levado a observar mais atentamente os "fatos" relevantes e o critério "legal" relevante. As decisões voltam-se para interpretações contextuais sobre os fatos e o direito - interpretações essas que, por definição, não podem mais ser justificadas por tais fatos ou critérios.

A prática moderna tardia de resolver disputas de soberania dificilmente passa de declarações levianas no que tange às bases tradicionais do direito territorial. A decisão acerca de tais questões é atualmente pensada no sentido de tentar estabelecer a solução mais equitativa. ${ }^{40}$ O fato é que as várias interpretações e considerações

38 Caso "Eastern Greenland", PCIJ Rep Series A n. 53, p. 45-62.

39 Ibid, p. 64-74.

40 Ver o caso "Burkina Faso - Mali Frontier" [1986], ICJ Reports, p. 567-568, parág. 28 (e n. 48). pragmáticas, bem como a apreciação final acerca da equidade da solução proposta, não podem ser justificadas com base em regras jurídicas. Pelo contrário, apelar para o tipo de justiça imbuída nessa apreciação implica, a partir da perspectiva do Estado de Direito, nada mais que capitulação à arbitrariedade ou comprometimento do princípio da subjetividade do valor, necessário na busca de um Estado de Direito. Permita-me apresentar outro exemplo. Argumentou-se muitas vezes que a existência dos Estados constitui uma "questão de fato" e que o "reconhecimento" seria apenas "declaratório", e não "constitutivo", da soberania. Se os Estados fossem criados por um ato externo de reconhecimento, aos Estados existentes seria atribuído o direito político de decidir quais entidades desfrutariam da condição de sujeitos de direito. Isso entra em conflito com os princípios da autodeterminação e da igualdade, consequências lógicas da rejeição do direito natural. ${ }^{41}$

Contudo, até mesmo uma visão aparentemente realista e democrática como essa precisou pressupor a existência de certos critérios preexistentes por meio dos quais seria possível verificar se a estatalidade estava presente em alguma entidade ou não. O problema nunca foi, na realidade, que se questionasse seriamente o surgimento dos Estados como um processo sociológico e factual. O problema foi - e continua sendo - que as pessoas enxergam as consequências normativas do processo social por meio de critérios distintos e chegam a conclusões irreconciliáveis mesmo ao adotar os mesmos critérios.

Há, no entanto, certo grau de convergência em relação a um tema tão importante como a estatalidade. Essa convergência, contudo, pouco tem a ver com poder factual ou efetividade. Rodésia, Transkei e Taiwan nunca foram considerados Estados, ao contrário de Tuvalu e Mônaco. Mas explicar tais "anomalias" - a par de outros casos aparentemente intrigantes de estatalidade - simplesmente com base na visão "constitutiva" é, de igual modo, insatisfatório. As objeções originais ao caráter imperialista dessa teoria continuam tão válidas quanto a posição moderada de Lauterpacht, sobre o dever de reconhecer quando os critérios legais foram

41 O texto clássico continua a ser CHEN, T. C. The International Law of Recognition. Londres: Stevens, 1951. Ver também KATO, L. Recognition in international law: some thoughts on traditional theory, attitudes of and practice by african states. Indian Journal of International Law, [S.1.], vol. 10, p. 299-323, 1970. . 
cumpridos, continua a ser uma petição de princípio: ${ }^{42}$ se um Estado se recusa a reconhecer uma entidade ao considerar que esta preencheu os critérios relevantes, não faz muito sentido insistir na existência do dever. A questão volta-se para a interpretação das circunstâncias factuais ou do conteúdo da norma relevante. O verdadeiro problema é que se mostra impossível, no âmbito das premissas liberais, contestar qualquer interpretação envolvida de forma legítima. Sob tais premissas, as normas são "autointerpretativas", e pressupõe-se que cada Estado deva ter liberdade para interpretar o sentido dos eventos factuais circundantes. ${ }^{43}$

Essas anomalias de estatalidade, bem como o ressurgimento da consagrada prática de não reconhecimento a partir da Opinião sobre a Namíbia (1971), sugerem que a obtenção do título territorial de estatalidade - pelo menos se o assunto desfrutar de certa importância tem relação com aquilo que é decidido externamente. ${ }^{44}$ Entretanto, também revelam que crer que tal decisão possa ser compreendida como "conformidade a uma regra" requer uma regra ou uma imaginação flexíveis a tal ponto que nem a perspectiva jurídica nem a do fato puro merecem o crédito de tentar se impor sobre essa decisão.

Se a presença da qualidade da soberania em determinada entidade é difícil de explicar em termos de fatos puros ou regras jurídicas, tal dificuldade é muito maior no que tange às consequências da soberania. $\mathrm{O}$ fato de que as fronteiras da jurisdição doméstica são instáveis e de que a "soberania" tem sido aparentemente compatível com o isolamento hermético e a integração extensiva de um Estado, indica que quaisquer direitos ou liberdades que essa qualidade possa acarretar constitui, como a Corte Permanente de Justiça Internacional observou, uma "questão relativa" - dependente do teor das obrigações do Estado em dado momento no tempo. ${ }^{45}$ Em outras palavras, não há nada determinado que decorra da soberania como uma questão de "fato puro" - pelo contrário, o conteúdo da soberania parece determinável apenas à medida que se conhecem as obrigações de um Estado.

42 LAUTERPACHT, H. Recognition in International Law. Cambridge: Cambridge University Press, 1948.

43 Para uma reformulação profícua dessa questão (liberal), ver CHENG, B. Custom, the future of general state practice in a divided world. In: MACDONALD, R. St. J.; JOHNSTON, D. M. (Ed.). The Structure and Process of International Law: essays in legal philosophy doctrine and theory. Haia: Martinus Nijhoff, 1983. p. 513, 519-523.

44 Caso "Namibia” [1971], ICJ Rep, p. 51, 54, parág. 112, 117, 119.

45 Caso "Nationality Decrees", PCIJ Rep Series B, n. 4, p. 24.
Os juristas que adotam a "perspectiva jurídica" por vezes acreditam que tal conclusão valida plenamente sua posição. A "soberania" não é uma questão externa mas sim interna ao direito, uma síntese conveniente para os direitos, liberdades e competências que o direito atribui ao Estado - e que podem ser recuperados a qualquer tempo. ${ }^{46}$ Para resolver uma disputa de soberania, basta conferir o corpo de regras legais e verificar se o Estado tem a capacidade que alega por alocação legislativa.

O problema de tal conclusão, todavia, é que na maior parte das áreas de conduta estatal não há nenhum ato legislativo definitivo que estabeleça a competência do Estado de agir de determinada maneira. Ademais, e aqui há outro paradoxo, as regras mais importantes da aplicação geral parecem ser justamente aquelas que fixam o direito de jurisdição exclusiva, autodeterminação, não intervenção e soberania. Não basta que, se a soberania fosse reduzida a uma abstração não normativa, então o direito internacional pareceria ser uma enorme lacunanos faltaria também uma explicação atrelada, um princípio interpretativo para resolver diferenças de opinião acerca do conteúdo ou da aplicação das poucas regras específicas que poderíamos então discernir.

No que concerne à maior parte das áreas de conduta estatal desvinculadas de tratados, obrigações específicas são, ou podem ser, plausivelmente elaboradas para parecer ambíguas ou insuficientes. Nesse caso, a soberania do Estado - sua liberdade inicial - ressurgiria como um princípio normativo próprio: na ausência de proibições expressas, o Estado deve ser considerado livre. Esse princípio - o princípio Lótus $^{47}$ - não constitui apenas uma regra geral. Ele condensa o pressuposto de que o mero fato da estatalidade tem um viés normativo (direito da autodeterminação) e que, na ausência de proibições legislativas inequívocas, qualquer tentativa de solapar a liberdade inerente à soberania seria nada mais que uma restrição ilegítima.

A dificuldade envolvendo o princípio Lótus é dupla. Em primeiro lugar, todas as regras e princípios têm conteúdos mais ou menos indeterminados. Se a simples existência de interpretações divergentes fosse suficiente para desencadear a presunção de liberdade, então a

46 SCHWARZENBERGER, G. The Forms of Sovereignty. Current Legal Problems, [S.1.], v. 10, p. 248, 1957.; HART, H. L. A. The Concept of Law. Oxford: Clarendon, 1961. p. 218.

47 Caso "Lotus", PCIJ Rep Series A, n. 10, p. 30. Ver também Koskenniemi, From Apology to Utopia (2005), p. 255-258. 
força vinculativa da maioria das regras seria considerada uma ilusão. Em segundo lugar, o que envolve um entrave ainda maior, tal princípio é inútil se o caso envolver um conflito de liberdades. Contudo, se se pressupor - algo inevitável se a ideia de um direito natural material for descartada - que as liberdades de um Estado são delimitadas pelas de outro, então qualquer disputa referente aos direitos ou deveres de dois ou mais Estados pode ser conceitualizada no sentido de um conflito de suas liberdades e, consequentemente, não pareceria passível de solução simplesmente mediante uma adesão à "liberdade" - tendo em vista que não saberíamos qual liberdade preferir.

Nesse ponto, a prática jurídica rompe com o ciclo argumentativo ao recorrer à equidade - um senso indiferenciado de justiça.

Disputas em torno de plataformas continentais constituem um exemplo disso. A Corte Internacional de Justiça (CIJ), como é amplamente conhecido, partiu do pressuposto de que o direito à plataforma continental era uma questão de aplicar o direito ab initio e ipso facto do Estado costeiro. Não se tratava de uma questão de "justiça abstrata" mas de fato (objetivo). ${ }^{48}$ Todavia, essa visão tem sido de pouca utilidade. A decisão de quais fatos são relevantes - o problema crucial - é tomada pela Corte de forma ad hoc e não se inscreve em nenhum código transcendental ex ante. Demarcações posteriores deixaram até mesmo de fingir adesão à teoria ipso facto/ ab initio e compreenderam que "alcançar um resultado equitativo" seria a tarefa correta a cumprir. ${ }^{49} \mathrm{~A}$ história do argumento em casos de plataformas continentais consiste na história da Corte constatando primeiro a ausência, ou pelo menos a ambiguidade da regra relevante e em seguida apelando para a perspectiva do fato puro (ipso facto); depois abandonando tal visão (porque nenhum "fato" pode ser normativo sem um critério anterior) em prol de um perspectiva jurídica (equidade infra legem ${ }^{50}$ como a regra correta), com todo o ciclo culminando na dispersão do conteúdo daquela regra no âmbito da justiça - justiça essa que pode, sob o princípio do valor subjetivo e do Estado de Direito, ser vista

48 Casos "North Sea Continental Shelf" [1969], ICJ Reports, p. 22-23, parág. 19-20.

49 Caso "Tunisia-Libya Continental Shelf" [1982], ICJ Reports, p. 59, parág. 70; caso "Gulf of Maine" [1984], ICJ Reports, p. 312, parág. 155; caso "Libya-Malta Continental Shelf” [1985], ICJ Reports, p. 38-39, parág. 49.

50 Casos "North Sea Continental Shelf" [1969], ICJ Reports, p. 20-22, parág. 15-20. apenas como arbitrária. ${ }^{51}$

A poluição transfronteiriça, para tomarmos outro exemplo, envolve a justaposição das liberdades do Estado-fonte e do Estado-alvo: por um lado, existe o direito soberano do Estado-fonte de explorar seus recursos naturais em conformidade com suas próprias políticas ambientais; por outro, há o direito exclusivo da vítima de decidir quais atos devem ocorrer em seus territórios. ${ }^{52}$ A liberdade do Estado-fonte de buscar usos economicamente benéficos de seu território contrasta com a liberdade do Estado-alvo de desfrutar de um meio ambiente puro. A simples opção pela "liberdade", ou por um direito inscrito na própria noção de soberania, torna o conflito sem solução. Um equilíbrio mostra-se inevitável na busca por uma decisão. ${ }^{53}$

Uma estrutura semelhante manifesta-se por toda a doutrina da soberania. Ao passo que a imunidade soberana costuma ser apresentada em termos da (do puro fato da) soberania ou de uma necessidade sistemática de comunicação internacional, a prática jurídica tende a estabelecer a isenção do soberano estrangeiro em relação à jurisdição local equilibrando os interesses de ambos os soberanos entre si. $^{54} \mathrm{O}$ mesmo parece valer nos casos que tratam da determinação do alcance permitido da jurisdição extraterritorial de um Estado. ${ }^{55} \mathrm{O}$ direito que trata dos usos de cursos d'água ${ }^{56}$ e de recursos de pesca internacionais, ${ }^{57}$ bem como os conflitos concernentes a

51 Para tal crítica, ver, por exemplo, a opinião divergente de Gros sobre o caso "Tunisia-Libya Continental Shelf" [1982], ICJ Reports, p. 151-156, e o caso "Gulf of Maine" [1984], ICJ Reports, p. 378-380. 52 Princípio 21 Da Conferência Da Onu sobre o Meio Ambiente Humano, 1972, Estocolmo. UN Doc A/CONF48/14, 1972.

53 Ver, por exemplo, KOSKENNIEMI, M. International Pollution in the Systems of International Law. Oikeustiede-Jurisprudentia, [S.l.], v. 17, p. 152-164, 1984.; LAMMERS, J. 'Balancing the equities' international environmental law. Recueil des Cours de l'Académie de droit international de la Haye, [S.1.], p. 153-165, 1984. p. 153-165.

54 CRAWFORD, J. international law and foreign sovereigns, distinguishing immune transactions. The British Yearbook of International Law, [S.1.], v. 54, p. 114-118, 1983. p. 114-118.

55 MENG, W. Völkerrechtliche zulässigkeit und grenzen der wirtschaftsverwaltungsrechtlichen hoheitsakte mit auslandswirkung. Zeitschrift für ausländisches öffentliches Recht und Völkerrecht, [S.I.], v. 44, p. 675-783, 1984. p. 675-783; LOWE, A.V. The problem of extraterritorial jurisdiction: economic sovereignty and the search for a solution. International \& Comparative Law Quarterly, [S.l.], v. 34, p. 730, 1985. p. 730.

56 SCHWEBEL, S. Third report on the non-navigational uses of international watercourses. Yearbook of the International Law Commission, [S.1.], p. 75-100, 1982. p. 75-100.

$57{ }^{56}$ Casos "Fisheries Jurisdiction" [1974], ICJ Reports, p. 30, parág. 69-70. 
investimentos estrangeiros entre o Estado de origem e o Estado de acolhimento, ${ }^{58}$ implicam o estabelecimento de um limite entre os dois soberanos, ou seja, uma determinação da extensão de sua liberdade soberana. $\mathrm{Na}$ ausência de regras determinadas e na impossibilidade de preferir um soberano ao outro, a prática jurídica tem-se voltado para a equidade no intuito de justificar a delimitação das duas soberanias entre si.

A substância do direito no âmbito da soberania tem se dispersado em um chamado generalizado por soluções equitativas ou "equilibradas" à medida que os conflitos surgem. Justificativas acadêmicas convencionais no que tange aos direitos de Estado, como consequência do fato puro da estatalidade ou estabelecidos por meio de legislação, não são aplicáveis. Nem podem sê-lo, uma vez que nem "fatos" nem "regras" são autoevidentes no sentido que os juristas liberais um dia imaginaram. Os fatos que supostamente estabelecem títulos não surgem "automaticamente", mas resultam da escolha de um critério a partir do qual os fatos podem ser imbuídos de importância normativa. ${ }^{59}$ Contudo, as regras também são sempre sujeitas à interpretação. A fim de associar-se a algo tangível, uma interpretação deveria remeter a determinado tipo de fatos. Para estabelecer o sentido dos fatos, devemos adotar a perspectiva de uma regra; para resolver controvérsias interpretativas sobre a regra, devemos - segundo a concepção social - observar os fatos. Daí o silêncio da modernidade tardia em relação a justificativas teoréticas e o salto a um consenso ad hoc.

\subsection{Fontes}

Não obstante sua ênfase inicial no poder efetivo, a doutrina da soberania parecia impraticável em virtude da forma abstrata e arbitrária com que se definia seu conteúdo normativo. É possível recomeçar do zero e imaginar que o direito internacional poderia muito bem ser descrito não como consequência da estatalidade, mas por meio de um conjunto de critérios normativos - fontes - para a criação e identificação de um corpo jurídico.

Não surpreende que a doutrina das fontes seja eivada

58 O prêmio LIAMCO [1981], ILR, vol. 20, p. 76-77, parág. 150-151.

59 "No domínio do direito não existe um fato em si mesmo, um fato imediatamente evidente; há somente fatos certificados pelas autoridades competentes em um procedimento estabelecido por lei". KELSEN, H. Principles of International Law. Nova York: Rinehart and Winston, 1966. p. 388. de dualismos que expressam, de várias maneiras, o impulso conflitante das demandas por concretude e normatividade. A própria doutrina é muitas vezes entendida a partir de duas perspectivas: como uma descrição dos processos sociais por meio dos quais os Estados criam o direito (concretude) e como uma metodologia para verificar o conteúdo do direito independentemente de opiniões políticas (normatividade). Ao integrar ambas as perspectivas, a doutrina das fontes pode manter sua aparente objetividade. Por um lado, determinado direito não poderia ser considerado como tal simplesmente em decorrência do valor de seu conteúdo, mas como resultado de um processo social. Por outro, a existência de fontes como metodologia restritiva estabelece o devido distanciamento entre esta e o que quer que os Estados possam desejar em determinado momento no tempo.

Embora não haja nenhum desacordo significativo entre os juristas internacionalistas acerca da correta enumeração de fontes (tratados, costumes, princípios gerais), a força retórica das fontes ("força vinculativa") é definida a partir de pontos de vista contrastantes. Sua importância às vezes relaciona-se com sua capacidade de refletir a vontade estatal (consensualismo). Em outros momentos, tal força vinculativa associa-se à relação dos argumentos das fontes com o que é “justo”, "razoável", "em conformidade com a boa-fé" ou alguma outra metáfora não consensual.

Disputas ordinárias sobre o conteúdo ou a aplicação de normas jurídicas internacionais empregam a contradição entre consenso e explicações pautadas na justiça. Uma parte elabora argumentos no sentido do consenso, ao passo que a outra o faz em termos do que é justo (razoável etc.). Todavia, nenhum desses argumentos é plenamente justificável por si só. Um argumento puramente consensual não é capaz de justificar, em definitivo, a aplicação de uma norma contra Estados não conscientes (apologismo). Um argumento que se apoie apenas em uma noção de justiça viola o princípio da subjetividade do valor (utopismo). Portanto, ambos devem apoiar-se mutuamente. Os argumentos vinculados ao consenso devem expor a relevância e o conteúdo deste no sentido daquilo que parece justo. Os argumentos associados à justiça devem demonstrar sua correção fazendo referência àquilo que os Estados consentiram. Uma vez que esses movimentos (consenso para a justiça; justiça para o consenso) fazem com que as posições inicialmente opostas pareçam iguais, nenhuma solução pode ser adotada por meio da simples escolha de uma 
delas. Uma solução somente parece possível na medida em que se decide o que os Estados "realmente" desejam ou o que o conteúdo da justiça "realmente" é. Nenhuma dessas perguntas, entretanto, pode ser respondida com base nas premissas do Estado de Direito. ${ }^{60}$

Para o jurista moderno, é muito difícil vislumbrar, e mais ainda justificar, um direito que se divorciaria daquilo que os Estados entendem ou desejam como o direito. A aparente necessidade de consensualismo parece pautar-se na própria crítica à noção de normas naturais como superstição. No entanto, as críticas ao consensualismo pleno - sua circularidade lógica, seu distanciamento da experiência, seu apologismo inerente - são notórias. ${ }^{61} \mathrm{O}$ consensualismo não é capaz de justificar a aplicação de uma norma contra um Estado que se opõe a tal aplicação a menos que crie uma distância entre a norma e a vontade momentânea do Estado em questão. Já se explicou, por exemplo, que, embora o direito surja do consenso, ele não carece do consenso de todo e qualquer Estado todo o tempo, e que um acordo geral, uma volonté générale ou uma Vereinbarung basta para a aplicação da norma. ${ }^{62}$

Todavia, tais explicações violam o princípio da igualdade soberana - elas não conseguem dar conta de por que um Estado deve estar circunscrito à vontade de outro. Obviamente, essa questão pode ser definida a partir de determinado conceito de necessidade social. Entretanto, nesse caso já nos afastamos do consensualismo puro e nos deparamos com a dificuldade de explicar o status legal dessa suposta necessidade e a razão pela qual deveria apoiar uma norma em detrimento de outra.

Uma estratégia mais comum consiste em explicar que o Estado originalmente consentiu (por meio de reconhecimento, aquiescência, ausência de protesto ou concordância “tácita”), apesar de agora negar tê-lo feito. Tal argumento é de extrema importância no âmbito do discurso liberal de legitimação. Ele permite que se defenda a restrição social de forma consensual à medida que se apliquem restrições contra um Estado que nega seu consenso. ${ }^{63}$ Todavia, nem mesmo esse argumento é

60 Ver também Kennedy, International Legal Structures (1987), p. 11-107.

61 KOSKENNIEMI, M. From Apology to Utopia: the structure of international legal argument. Cambridge: Cambridge University Press, 2005.p. 309-313.

62 Como exemplo de texto clássico do tema, ver TRIEPEL, H. Völkerrecht und Landesrecht. Leipzig: Hirschfeld, 1899. p. 27, 51-53.

63 Ver, por exemplo, o argumento em BLECKMANN, A. Grund- convincente, tendo em vista que ele deve explicar-se a si próprio, em última instância, de forma plenamente consensual ou plenamente não consensual e, assim, passa a ser vulnerável às objeções em torno do apologismo ou do utopismo.

Por que determinado Estado deveria estar vinculado a um argumento segundo o qual ele consentiu, mesmo que "de forma tácita"? Se a razão for dada no sentido de respeitar seu próprio consenso, então devemos explicar por que temos mais condições que o próprio Estado de saber o que este consentiu. Até mesmo os consensualistas costumam admitir que tal conhecimento não está aberto a observadores externos. Contudo, mesmo se fosse possível "saber mais", tal argumento não é efetivamente defensável no âmbito das premissas do Estado de Direito. Imbuída nele está a desagradável implicação de que não poderíamos mais nos pautar na vontade expressa do sujeito de direito. $\mathrm{O}$ argumento perderia a justificativa central por trás da legislação democrática e tornaria válido o estabelecimento de um Leviatã - aquele que sabe melhor que ninguém o que as pessoas "realmente" desejam. Trata-se de uma estratégia para introduzir opiniões autoritárias sob um disfarce democrático.

Teóricos do consenso tácito costumam explicar que não se trata de uma questão de vontade "real" mas sim "presumida". Mas então o que permite a aplicação da presunção contra um Estado que nega jamais ter consentido a algo do gênero? Nesse ponto, o jurista defensor do consenso tácito deve afastar-se do consensualismo rumo ao não consensualismo. $\mathrm{O}$ consenso tácito - ou a presunção de consenso - é vinculativo porque é "justo" ou conforma-se com a razoabilidade ou boa-fé, ou porque protege expectativas legítimas ou algo do tipo. ${ }^{64}$ Agora a dificuldade consiste em defender a posição não consensual assumida. Sob o princípio do valor subjetivo, porém, a "justiça” não pode ser discutida de forma não arbitrária. ${ }^{65}$ De outro modo, o Estado de Direito seria inútil ou mesmo abertamente prejudicial.

probleme und Methoden des Völkerrechts. Freiburg: Alber, 1982. p. 81, 184-189. Sobre a construção do consenso tácito de forma geral, ver KOSKENNIEMI, M. From Apology to Utopia: the structure of international legal argument. Cambridge: Cambridge University Press, 2005.p. 325-333.

64 Ver, por exemplo, MÜLLER, J. P. Vertrauenschutz im Völkerrecht. Colônia: Heymann's, 1970.; MARTIN, A. L'estoppel en droit international public. Paris: Pedone, 1979.

65 ZOLLER, E. La bonne foi en droit international public. Paris: Pedone, 1977. p. 345. 
Seria possível afirmar, obviamente, que uma noção de razoabilidade se justifica porque o próprio Estado em questão a aceitou. Todavia, essa defesa trará de volta à cena o problema de como é possível opor uma justificativa consensual a um Estado que refute sua validade e assim por diante, ad infinitum.

No caso do Golfo de Maine (1984), o Canadá argumentou que os Estados Unidos estavam vinculados a determinada linha de delimitação, tendo em vista que não havia protestado contra seu uso de facto. Apoiado na ausência de protesto, o Canadá, por um lado, alegou o consenso estadunidense em relação à sua vinculação e, por outro, fez referência à boa-fé e à equidade. Sua argumentação apelou tanto para o consenso quanto para a justiça. A Câmara da CIJ aceitou ambas as explanações, começando pela última, de natureza não consensual. $\mathrm{O}$ que é comum à aquiescência e à preclusão é o fato de que "[...] ambas decorrem do princípio fundamental da boa-fé e equidade". ${ }^{66}$

Caso a Corte tivesse seguido essa linha de raciocínio, ela deveria - porque nem todo silêncio cria normas - ter se envolvido em uma discussão sobre se as condições de boa-fé ou equidade faziam-se ou não presentes para vincular os Estados Unidos naquele momento. Contudo, tal discussão não aconteceu. Isso é compreensível, uma vez que argumentar com base na justiça não consensual parece altamente subjetivo e abstrato. Em vez disso, a Corte voltou-se para um entendimento consensual sobre a dependência da ausência de protesto e em seguida passou a debater se a "carta de Hoffmann" enviada pela administração estadunidense às autoridades canadenses era uma prova da aceitação dos Estados Unidos acerca da equidistância do Canadá. Não era: “[...] fatos invocados pelo Canadá não levam à conclusão de que o governo dos Estados Unidos reconhecia a linha mediana...". ${ }^{67}$

Em outras palavras, os Estados Unidos não estavam vinculados porque não havia intenção subjetiva (independentemente de considerações de boa-fé ou equidade). Como a Corte chegou a essa conclusão? Não por contar com a (ausência de) intenção real dos Estados Unidos de se vincular; isso teria sido apologético e uma violação da soberania canadense. A conclusão da Câmara não abordou uma falta de intenção "real", mas sim de intenção "construtiva" por parte dos EUA. Em quais

66 Caso “Gulf of Maine” [1984], ICJ Reports, p. 305, parág. 130.

67 Ibid, p. 307, parág. 138. princípios pautava-se tal construção? Sobretudo na inconsistência dos fatos e no status governamental inferior das autoridades envolvidas. ${ }^{68}$ Todavia, o que justificou essa escolha de fatos relevantes e sua consequente interpretação? O que fez a construção da Corte superar a canadense? $\mathrm{O}$ argumento termina aqui. Os princípios de construção não foram discutidos.

Em tese, a Câmara poderia ter empregado dois princípios de construção: 1) uma construção é justificada se corresponder à intenção; 2) uma construção é justificada se for um reflexo da justiça não consensual. Trata-se de justificativas excludentes. No entanto, nenhuma delas mostrava-se acessível para a Câmara. Descartou-se a primeira em virtude do argumento anterior que excluiu a possibilidade de se conhecer a verdadeira intenção norte-americana e de usá-la contra o Canadá. Descartou-se a segunda porque ela teria exigido uma argumentação inteiramente não consensual contra as justificativas não consensuais canadenses. Tal estratégia teria adquirido a correção de uma justiça objetiva e teria entrado em conflito com a recusa prévia da Câmara de pensar a relação aquiescência-preclusão de forma inteiramente não consensual. A Câmara simplesmente adotou uma interpretação da conduta norte-americana que divergia da do Canadá. O porquê de ser uma interpretação melhor não foi debatido uma vez que não poderia tê-lo sido. A decisão não foi, segundo seus próprios pressupostos, determinada por um argumento jurídico.

Uma estrutura argumentativa idêntica é observada no âmbito da interpretação de tratados. Interpretações específicas remetem ou à vontade de determinada parte ou a alguma noção de boa-fé, razoabilidade etc. ${ }^{69}$ Uma vez que a vontade "real" de uma parte não é passível de ser identificada e justificadamente oposta a outra parte que negue tal intenção, e tendo em vista que o conteúdo daquilo que seja uma interpretação "justa" não pode ser estabelecido de maneira legal, as doutrinas da modernidade tardia costumam reconhecer o caráter estético, impressionístico do processo interpretativo. ${ }^{70}$ Aspectos polêmicos concernentes à vontade de determinada parte vão de encontro a aspectos igualmente controversos

\section{Ibid.}

69 Em relação a esse contraste de forma geral, ver, por exemplo, ZOLLER, E. La bonne foi en droit international public. Paris: Pedone, 1977. p. 205-244.

70 SUR, S. L'interpretation en droit international public. Paris: LGDJ, 1974. Ver também McDougal, "International Law, Power and Policy" (1953), p. 149-157. 
a respeito da justiça de interpretações específicas.

No caso Interpretação das declarações argelinas de 19 de janeiro de 1981, o Tribunal Arbitral Irã-Estados Unidos deveria decidir se o artigo $2^{\circ}$ da Declaração de Resolução de Litígios atribuía ao Irã o direito de prestar queixas contra cidadãos estadunidenses. A maioria concluiu que a questão não poderia ser interpretada dessa forma. Uma "formulação clara" daquele artigo excluía queixas iranianas da jurisdição do tribunal. Tal formulação desfrutava de autoridade por ser o exemplo mais evidente de consenso entre as partes. ${ }^{71}$ Uma minoria argumentava que uma construção literal não era capaz de concretizar o caráter recíproco do acordo. Segundo essa minoria, a reciprocidade constituía a própria razão de o Irã ter aceitado participar do acordo. Ao excluir a reciprocidade, a maioria violou o consenso iraniano e injustificadamente preferiu a justiça da literalidade à justiça da reciprocidade. $^{72}$ Ambos os lados evocam consenso e justiça, mas são incapazes de se referir diretamente às perspectivas do outro. Nenhum deles pauta sua argumentação na questão do "consenso real". Contudo, ao passo que a maioria enxerga a manifestação do consenso no texto, a minoria enxerga-o no âmbito da reciprocidade. Ambos os lados afirmam que seu princípio interpretativo é melhor na medida em que melhor reflete o consenso. Todavia, decidir a disputa com base em tais argumentos exigiria uma maneira de constatar o consenso a despeito de suas manifestações - uma possibilidade rejeitada à medida que se fez referência às manifestações em virtude do pressuposto de que não se poderia ter acesso ao consenso real. Ademais, nem podem os dois lados alegar que sua justiça - a justiça da literalidade ou da reciprocidade - é melhor sem uma argumentação que parta de uma teoria da justiça aparentemente indefensável sob o Estado de Direito. Em última instância, ambas as interpretações são incontestes. Uma doutrina que exclui argumentos oriundos de "um conhecimento maior" e da justiça natural não tem os meios de decidir sobre a superioridade de interpretações conflitantes.

As tentativas de explicar por que os Estados deveriam ser vinculados por declarações unilaterais enfrentam problemas semelhantes. Em primeiro lugar, como a CIJ apontou no caso dos Testes Nucleares (1974), tais afirmações podem ser vinculativas "[q]uando for intenção

71 Tribunal Arbitral Irã-Estados Unidos, "Interpretation of the Algerian Declaration of 19th January 1981" [1982], ILR, vol. 62, p. 599600 .

72 Ibid, p. 603-606. do Estado proponente da declaração tornar-se vinculado segundo seus próprios termos". ${ }^{73}$ Todavia, sua força vinculativa não pode ser inteiramente consensual porque assim o Estado poderia se ver livre simplesmente por um novo ato de vontade. Portanto, a Corte observou também que

$[\mathrm{u}] \mathrm{m}$ dos princípios que governam a criação e o
desempenho de obrigações legais [...] é o princípio
da boa-fé $[\ldots]$. Assim, os Estados interessados
podem tomar conhecimento de declarações
unilaterais e depositar confiança nelas, e têm o
direito de exigir que a obrigação ora criada seja
respeitada. ${ }^{74}$

Agora o Estado declarante encontra-se vinculado a despeito de sua vontade, com base na simples afirmação e dependência de terceiros.

A necessidade de propor os dois argumentos parece óbvia. O primeiro argumento - consensual - da Corte justificou a vinculação da França às suas declarações. Entretanto, tal argumento pareceu também ameaçador na medida em que dava a entender que a França poderia modificar ou encerrar sua obrigação a seu bel-prazer. Isso violaria as vontades e a soberania dos requerentes (Austrália e Nova Zelândia). O segundo argumento não consensual - a respeito da boa-fé e de expectativas legítimas mostrou-se necessário para defender estas últimas. A decisão foi, ao mesmo tempo, consensualista e não consensualista. Ela permitiu que a norma a ser aplicada fosse pautada na defesa da soberania de cada Estado envolvido. Simultaneamente, pareceu dar efeito àquilo que a justiça aparentava exigir.

Contudo, a decisão também se mantém vulnerável sob cada uma dessas perspectivas. Como a Corte pôde pautar sua norma no consenso francês diante de uma clara negação de qualquer consenso por parte daquele país? Ela não explica como pode ser capaz de defender a dependência dos requerentes enquanto estes negam a existência dessa dependência. A Corte também deixa sem explicação sua teoria da justiça, segundo a qual essas declarações e ações têm efeito vinculativo nessas circunstâncias em conformidade com a boa-fé.

A estrutura, importância e fragilidades do consenso tácito fazem-se mais visíveis no argumento ortodoxo a respeito do direito internacional consuetudinário.

Segundo esse argumento, um costume vinculativo

73 Casos "Nuclear Tests” [1974], ICJ Reports, p. 267, parág. 43.

74 Ibid, p. 268. 
existe se houver uma prática material de Estados para esse efeito e se tal prática for motivada pela crença em sua obrigatoriedade. Essa "teoria dos dois elementos" exprime o princípio da sociologia liberal, para a qual o sentido - direito ou não direito? - da ação social não reside em sua aparência externa nem naquilo que se possa pensar a respeito dela, mas sim em uma conjunção de ambos: um elemento externo (material) e outro interno (psicológico). ${ }^{75} \mathrm{~A}$ função do primeiro elemento é garantir que determinado costume possa ser constatado a despeito das perspectivas políticas momentâneas dos Estados. A função do segundo é distinguir o costume da coerção.

O problema com a teoria dos dois elementos é que nenhum deles pode ser identificado independentemente do outro. Portanto, um não pode ser usado para impedir o surgimento do Senhor Hyde ${ }^{76}$ no outro.

Os juristas contemporâneos têm rejeitado explicações totalmente materialísticas de costumes como sendo apologéticas, incapazes de diferenciar restrição factual e direito. Se a possibilidade de que tal distinção possa ser feita pela justiça do comportamento relevante for descartada, então ela só pode ser estabelecida por intermédio do elemento psicológico, a opinio juris. Todavia, como muitos alunos da jurisprudência da CIJ têm demonstrado, não há critérios aplicáveis de modo independente para verificar a presença da opinio juris. A CIJ tem simplesmente inferido sua presença ou ausência a partir da extensão e intensidade da prática material sobre a qual tem se debruçado. ${ }^{77}$ Ademais, nem parece possível pressupor a existência de tais critérios e que a opinio recebida poderia contrapor-se a um Estado não anuente. Este seria um argumento relativo ao deveria "saber mais". Em outras palavras, embora pareça possível distinguir "costume" daquilo que é realmente efetivo

75 Ver HART, H. L. A. The Concept of Law. Oxford: Oxford University Press,1961. p. 91. Para uma discussão do tema, ver KOSKENNIEMI, M. The Normative Force of Habit: International Custom and Social Theory. Finnish Yearbook of International Law, v. 1, p. 77, (1990).

76 Alterego psicopata do doutor Henry Jekyll na novela gótica $O$ médico e o monstro, de Robert Louis Stevenson [N.T.].

77 Ver, por exemplo, SØRENSEN, M. Les sources du droit international. Copenhague: Munskgaard, 1946. p. 108-111; VIRALLY, M. The Sources of International Law. In: SØRENSEN, M. (Ed.). Manual of Public International Law. Londres: Macmillan; Nova York: St Martin's Press, 1968. p. 134-135; H. Günther, Zur Enststehung von Völkergewohnheitsrecht (Berlim, Duncker \& Humblot, 1970), p. 70. Ver também KOSKENNIEMI, Martti. From Apology to Utopia. Cambridge: Cambridge University Press, 2005. p. 428-429. recorrendo-se apenas àquilo em que os Estado acreditam, tais crenças não parecem estar aptas à identificação, independentemente do que seja, de fato, efetivo.

Poder-se-ia tentar evitar essa circularidade com a pressuposição de que alguns tipos de comportamento são por natureza - "de modo intrínseco" - a ponto de gerar (ou não) um costume normativo. Contudo, os esforços em discriminar listas de tais tipos têm se mostrado infrutíferos. Um conceito "flexível" de prática material tem vindo à tona: qualquer ato ou declaração pode ser considerado uma prática geradora de costumes se os Estados assim o desejarem ${ }^{78}$ (na realidade, qualquer outra conclusão expressaria um naturalismo ilegítimo e violaria os princípios da sociologia liberal: isto é, deixaria de considerar o "aspecto interno"). O uso desse critério (o que é que os Estados desejam), todavia, implicaria conhecer a opinio independentemente do ato que a expressa. Essa possibilidade, porém, já havia sido descartada por nosso argumento anterior acerca da necessidade de atentar para práticas materiais desde o princípio. De fato, se pudéssemos conhecer as intenções dos Estados a despeito do que fazem, toda a teoria dos dois elementos se tornaria desnecessária: poderíamos simplesmente colocar tais intenções em prática. Um costume, então, se aglutinaria a um acordo (informal) (nesse caso, obviamente, enfrentaríamos a dificuldade de ter que interpretar o conteúdo inserido em qualquer acordo desse tipo ao recorrer às "verdadeiras" vontades das partes ou a alguma noção de justiça, conforme foi explicado anteriormente).

A doutrina do direito consuetudinário permanece indeterminada em virtude de sua circularidade. Ela pressupõe que dado comportamento é uma prova das intenções dos Estados (opinio juris) e que estas evidenciam qual comportamento é relevante como costume. A fim de evitar o apologismo (contando com a vontade atual de um Estado), a doutrina em questão encara o elemento psicológico a partir da perspectiva do material; a fim de evitar o utopismo (distinguindo usos vinculativos e não vinculativos ao recorrer àquilo que é justo), ela encara o elemento material a partir da perspectiva do psicológico. Esta doutrina não pode ocupar nenhuma dessas posições de modo permanente sem

78 Ver, por exemplo, BRAVO, L. Ferrari. La coutume internationale dans la pratique des etats. Recueil des Cours de l'Académie de droit international de la Haye, [S.1.], v. 192, p. 243, 1985. p. 243, 261; KOSKENNIEMI, Martti. From Apology to Utopia. Cambridge: Cambridge University Press, 2005. p. 431-432. 
se tornar vulnerável a críticas emitidas pela outra. As próprias pressuposições subjacentes ao direito internacional consuetudinário oferecem o mecanismo para sua autodestruição.

Para a prática internacional da modernidade tardia, a teoria convencional é cada vez mais um disfarce para o que é, na verdade, uma tentativa de compreender os costumes em termos de uma equidade bilateral. A CIJ, por exemplo, sempre se mostrou até certo ponto ambígua no que se refere ao caráter das regras do direito não escrito que ela estabeleceu. Seu argumento sobre o costume relevante nos casos da Zona Pesqueira (Reino Unido v. Noruega) (1951) e da Competência em Matéria Pesqueira (Reino Unido v. Islândia) (1974) abordou o problema mais em termos do interesse relevante em jogo que da tentativa de encontrar alguma regra geral a ser "aplicada". ${ }^{79}$ Os diversos casos de fronteira marítima realçaram ainda mais essa tendência. O julgamento do caso Atividades Militares e Paramilitares na e Contra a Nicarágua (Nicarágua v. Estados Unidos da América) (1986) nem se esforçou seriamente em justificar suas quatro regras consuetudinárias - não uso da força, não intervenção, respeito à soberania e, sobretudo, normas humanitárias relevantes - em termos da prática material e da opinio juris. ${ }^{80}$ Muitas pessoas têm se mostrado insatisfeitas com a estratégia moderna de defender qualquer padrão não escrito como "costume". Sir Robert Jennings, dentre outros, tem observado que aquilo que nos habituamos a chamar de costume "não apenas não é direito consuetudinário: não lembra nem de longe um direito consuetudinário" ${ }^{81}$ Contudo, se um padrão não escrito não for argumentável em termos de práticas materiais ou de crenças relativas a elas, então ele só pode existir como direito natural - defensável apenas mediante a importância política de seu conteúdo. De fato, grande parte da prática da CIJ a esse respeito permanece ex cathedra: a instituição tem "fixado um sistema de tomada de decisão em que a conclusão obtida é determinada pela aplicação de regras consideradas, em larga medida, autoevidentes". ${ }^{82} \mathrm{Na}$ realidade, muitas vezes há consen-

79 Caso "Anglo-Norwegian" [1951], ICJ Reports, p. 133; casos "Fisheries Jurisdiction" [1974], ICJ Reports, p. 30-33 [69]-[79].

80 Caso "US Military and Paramilitary Activities" [1986], ICJ Reports, p. 97-115 [183]-[220].

81 JENNINGS, R. The identification of international law. In: CHENG, B. (Ed.). International Law, Teaching and Practice. Londres: Stevens, 1982. p. 5.

82 KEARNEY, C. Sources of Law and the International Court of Justice. In: Gross, L. (Ed.). The Future of the International Court of so em torno de tais regras, como atestam as "considerações básicas de humanidade" evocadas pela Corte no caso do Canal de Corfu (1949). Entretanto, o problema é claramente menos uma questão de explicar por que as pessoas que concordam são vinculadas e mais de explicar por que aquelas que discordam devem ser vinculadas, bem como de que forma se deveria argumentar no caso de controvérsias interpretativas virem à tona.

\section{A POLÍtICA DO DIREITO INTERNACIONAL}

A ideia de um Estado de Direito internacional tem adquirido credibilidade na medida em que o esforço por configurá-lo não implica um compromisso com o conteúdo das normas porventura estabelecidas ou com o caráter da sociedade que se consolidou. As potências europeias do século XIX puderam começar a pensar sobre suas relações em termos de regras jurídicas porque formalizaram relações intersoberanas e porque nenhuma soberania precisou constatar que suas políticas substanciais eram descartadas por tais relações. A Assembleia-Geral da ONU pôde aceitar, via consenso, a declaração da "Década da Lei Internacional" em 1989 com base nessas mesmas razões. Isso é fortemente salientado pelo fato de que a declaração não apresentou nenhum plano de ação substancial. O texto simplesmente apela para a promoção do respeito aos princípios do direito internacional e a resolução pacífica de disputas, bem como para o estímulo ao desenvolvimento e disseminação do direito internacional. Em contrapartida, não aborda a razão pela qual o direito deveria ser aplicado ou que tipo de regras ele deveria promover.

O direito internacional moderno constitui um arcabouço sofisticado de delegação para outros lugares de resoluções substanciais: para mais procedimentos, interpretações, equidade, contextos e assim por diante. A Convenção sobre o Direito do Mar de 1982 é um exemplo típico: em vez de uma lista identificando o que se deve ou não fazer, a Convenção estabelece um quadro que delimita poderes soberanos e designa jurisdições - com base no pressuposto de que os problemas substanciais dos usos do mar podem ser melhor resolvidos por meio da delegação do poder decisório a outras instâncias, incorrendo no contexto e em geral re-

Justice. Dobbs Ferry: Oceana Publications, 1976. p. 653. 
metendo a "princípios equitativos". ${ }^{83}$ O êxito do direito internacional depende dessa formalidade, dessa recusa em propor regras determinantes ou resoluções prontas a conflitos futuros. A despeito da existência de um "processo" claramente jurídico - e, nesse sentido, um sistema relativamente autônomo e coerente que pode ser abstraído de tratados acadêmicos -, não há padrões legais determinantes. Permita-me explicar essa questão de modo esquemático.

O Estado de Direito constitui uma tentativa de promover a vida comunitária sem abrir mão da autonomia individual. A vida comunitária é, obviamente, necessária para impedir que o individualismo incorra em anarquia ou tirania. $\mathrm{O}$ individualismo é necessário porque, de outro modo, continuaria a ser passível de objeção por parte daqueles que acreditam que o tipo de comunidade provido pelo Estado de Direito não atende a seus critérios políticos. A partir da perspectiva desses indivíduos, as pretensões comunitárias do direito culminariam em apologias totalitárias. ${ }^{84}$

O direito busca cumprir sua dupla função ao tornar-se formal: não adotando nem ideais comunitários específicos nem políticas de soberania específicas. Ou, de outro modo, uma regra, argumento ou doutrina jurídica aceitável é aquela que consegue se justificar tanto do ponto de vista da consolidação da comunidade (porque senão pareceria apologética) quanto da salvaguarda da soberania (porque senão suas implicações continuariam a ser totalitárias). O problema é que, assim que qualquer dessas justificativas seja apresentada para endossar algum tipo específico de existência comunitária ou algum limite determinado de autonomia soberana, elas tornam-se vulneráveis a partir de um ponto de vista substancial contrário. Portanto, enquanto um jurista justifica o resultado substancial de sua preferência com base na capacidade desse resultado de apoiar a comunidade, passa a ser simultaneamente possível para seu/sua homólogo/a - que não compartilha do mesmo ideal comunitário - desafiar essa mesma justificativa como totalitária. De modo análogo, uma regra, princípio ou solução justificada com base no modo como defende a soberania pode - para alguém que estabeleça os limites da "soberania" de ma-

83 Ver, de modo geral, ALLOTT, P. Power Sharing in the Law of the Sea. American Journal of International Law, [S.1.], v. 77, p. 1-30, 1983.

84 Ver também o artigo seminal de KENNEDY, D. The structure of blackstone's commentaries. Buffalo Law Review, [S.1.], v. 18, p. 205, 1979. neira distinta - ser passível de objeção por estimular o egoísmo e a anarquia.

Considere-se o caso da poluição transfronteiriça, por exemplo. Gases nocivos fluem de um Estado A para o território de um Estado B. O Estado A alega seu "direito soberano de usar seus recursos naturais em conformidade com suas políticas nacionais". O Estado $\mathrm{B}$ argumenta que o primeiro deve dar um basta na poluição, interpretando a posição do Estado A como egoísta ao mesmo tempo que faz seu próprio argumento parecer comunitário. Ele pode se referir a uma norma de "uso não danoso do território", por exemplo, e justificar tal alegação por meio de analogias a regras relativas a rios e recursos naturais internacionais, bem como de precedentes e resoluções da Assembleia Geral. ${ }^{85}$

O Estado A pode então rebater essa argumentação afirmando que as normas não podem se opor a ele de modo tão totalitário. Ele vincula-se apenas às normas que já aceitou, e nunca aceitou as analogias evocadas pelo Estado B. Isso forçaria o Estado B a argumentar que sua norma eleita é vinculativa a despeito de aceitação - em cujo caso ele teria algo a perder, tendo em vista que seu argumento pareceria utópico - ou a mudar de estratégia a fim de também atribuir à sua posição uma aura protetora da soberania. O Estado B pode então retrucar que a poluição viola sua própria liberdade e constitui uma interferência em seus assuntos internos, como fez a Austrália no caso Testes Nucleares. ${ }^{86}$ A posição do Estado B aparentaria ser, então, tanto comunitária (em relação ao Estado A) quanto individualista (em relação a si próprio).

Com o intuito de contestar esse último argumento apresentado pelo Estado B, o Estado A precisa fazer uma observação de cunho comunitário. Ele pode argumentar que existe uma norma concernente à boa vizinhança, a exemplo daquela alegada no caso Lago Lanoux (1957), a qual requer que os Estados tolerem inconvenientes menores resultantes de usos legítimos dos territórios de Estados vizinhos. ${ }^{87} \mathrm{O}$ Estado $\mathrm{B}$ não pode exigir integridade territorial completa. A posição do Estado A é agora tanto individualista (em relação a si próprio) quanto comunitária (em relação ao Estado B).

85 Para ambos os argumentos, ver o Princípio 21 da Declaração de Estocolmo (n. 51) e também KOSKENNIEMI, M. International Pollution in the Systems of International Law. Oikeustiede-Jurisprudentia, [S.1.], v. 17, p. 100-103, 1984.

86 Casos "Nuclear Tests", ICJ Pleadings, vol. I, p. 14.

87 Caso "Lake Lanoux", UNRIAA, vol. 12, p. 316. 
$\mathrm{O}$ argumento poderia seguir adiante. Ambas as partes poderiam reforçar o viés comunitário de suas posições fazendo referência à equidade, aos princípios gerais etc., a fim de rejeitar a autonomia (egoísmo) da parte opositora. Poderiam também salientar os argumentos de cunho soberano ao destacar ainda mais sua independência, consenso, integridade territorial, autodeterminação, etc., com o fito de refutar os argumentos comunitários (totalitários) do seu adversário. Consequentemente, o caso não poderia ser decidido pela simples preferência à autonomia em detrimento da comunidade ou vice-versa. Ambos os argumentos reforçam as duas posições. $\mathrm{O}$ caso não é passível de solução por meio da referência a qualquer dos conceitos disponíveis (soberania, uso não danoso do território, integridade territorial, independência, boa vizinhança, equidade etc.), uma vez que cada um desses conceitos pode ser elaborado de modo a corroborar qualquer uma das duas posições. Além disso, tais construções não seguem nenhuma preferência legalmente determinada. Uma corte poderia declarar que uma das posições é melhor no que se refere à equidade, por exemplo, ou tentar estabelecer um "equilíbrio" entre as alegações. Todavia, ao justificar sua concepção do que é equitativo, a corte terá que adotar uma teoria da justiça - teoria essa, porém, que não poderá justificar ao remeter mais uma vez aos próprios conceitos jurídicos.

Outro exemplo diz respeito às relações entre um investidor estrangeiro e o Estado anfitrião. A perspectiva que salienta o individualismo, a separação e o consenso pode vir à tona para reforçar a soberania desse Estado - seu direito de nacionalizar a empresa sem compensação "plena, imediata e adequada". Entretanto, a mesma posição pode decorrer de forma igualmente satisfatória de observações comunitárias relativas à justiça, à igualdade ou solidariedade ou ao caráter vinculativo da nova ordem econômica internacional, por exemplo. ${ }^{88} \mathrm{O}$ caso do Estado anfitrião pode ser defendido de forma semelhante, em que se enfatize sua liberdade, individualidade e consenso - conforme expresso na doutrina de direitos adquiridos - ou a natureza vinculativa não consensual da norma pacta sunt servanda, a boa-fé ou outras concepções pertinentes de justiça. Para efetuar uma escolha, o solucionador de problemas deveria simplesmente ter que optar por uma das soberanias - nesse caso a igualdade soberana é anulada - ou empregar outra teoria de

88 Ambas as justificativas para esse direito podem ser verificadas, por exemplo, na Carta dos Direitos e Deveres Econômicos dos Estados, UNGA Res. 3281 (XXIX) (12 dez. 1974). justiça (ou de equidade) que não pode, contudo, justificar com base no Estado de Direito. ${ }^{89}$

A relação entre os princípios da autodeterminação e da integridade territorial, ambos já sacralizados em inúmeras resoluções da Assembleia Geral da ONU, permanece um enigma. ${ }^{90} \mathrm{O}$ problema, da forma como o enxergamos agora, é que não se pode preferir nenhum dos princípios conflitantes na medida em que estes são, em última instância, iguais. Quando um povo clama por integridade territorial, ele exige respeito à sua identidade como entidade autodeterminada e vice-versa. A fim de solucionar o conflito, seria necessário um princípio externo a respeito de quais tipos de associação humana envolvem esse respeito ou não. Isso parece implicar uma argumentação pautada em visões políticas contestadas sobre o tipo de organização que o direito deveria almejar em termos materiais.

A formalidade do direito internacional torna possível a cada Estado compreender sua concepção substancial de sociedade global, bem como sua visão acerca do alcance da liberdade soberana em conceitos e categorias jurídicas. Não se trata aqui de uma distorção ao direito introduzida de fora. Trata-se, pois, de uma consequência necessária da visão segundo a qual inexiste uma "vida boa" natural, um limite à liberdade soberana que existiria por força de alguma necessidade histórica. Se esse tipo de naturalismo for rejeitado - e desde o Iluminismo, todos têm tido boas razões para fazê-lo -, então impor qualquer concepção substancial de vida comunitária ou de limites à soberania pode parecer nada mais que uma restrição ilegítima - expressa pela preferência às políticas de um Estado em detrimento das de outro.

É impossível tomar decisões substanciais no âmbito do direito que não implicariam nenhuma escolha política. O foco na equidade designado pela modernidade tardia nos diferentes domínios do direito internacional é, nesse sentido, a admissão sadia de algo que, para todos os efeitos, já existe: no fim das contas, legitimar ou criticar o comportamento estatal não é uma questão de

89 "Uma solução deveria, portanto, reconhecer o direito soberano do Estado de origem e do Estado de acolhimento ao investimento em questão e deveria esforçar-se por encontrar um equilíbrio equitativo entre eles", em I. Seidl-Hohenveldem, "International Economic Law. General Course on Public International Law" (1986), Recueil des Cours de l'Académie de droit international de la Haye, vol. 198, p. 54. 90 Ver UNGA Res. 1514 (XV), 14 dez. 1960; 2625 (XXV), 24 out. 1970, e os comentários, por exemplo, em M. Pomerance, SelfDetermination in Law and Practice; the New Doctrine in the United Nations (Boston, Nijhoff, 1982), p. $43-47$ e passim. 
aplicar formalmente regras neutras, pois depende daquilo que se considera politicamente certo ou justo.

\section{Considerações finais}

Os teóricos da atualidade muitas vezes explicam nossa condição pós-moderna como resultado de uma tragédia das perdas. Para os juristas internacionalistas, o Iluminismo significou a perda da fé em uma ordem natural de pessoas, nações e soberanias. A fim de conter o subjetivismo político, juristas dos séculos XIX e XX depositaram sua confiança, de modo variável, em lógica e textos, história e poder, com o intuito de encontrar um amparo objetivo e seguro. Cada tentativa culminou em decepção. $\mathrm{O}$ uso da lógica dependia de quais axiomas políticos eram inseridos como premissas. Textos, fatos e a história eram passíveis de ser interpretados das formas mais variadas. Ao elaborar suas interpretações, os juristas eram sempre levados a contar com matrizes conceituais que não podiam mais ser defendidas pelos textos, fatos ou histórias a que atribuíam significado. Tais matrizes eram e continuam sendo arenas de luta política.

Todavia, o retorno à fé inabalável de Vitoria ou de Suárez não se abre para nós. Simplesmente não podemos passar a crer que a política - justiça e equidade poderia ser debatida a ponto de todos concordarem no final. Isso nos ensina uma lição. Na medida em que o mundo, incluindo as concepções dos juristas a respeito dele, é conflituoso, qualquer projeto grandioso de uma “ordem mundial” estará sempre sob suspeição. Qualquer regra ou princípio jurídico e projeto de ordem mundial parecerá aceitável apenas quando for formulado de modo abstrato e formal. Ao ser aplicado, terá se sobreposto a alguma interpretação ou experiência coletiva e parecerá apologético.

Os teóricos sociais têm registrado uma recente virada moderna nas sociedades nacionais que se distancia do Rechtstaat rumo a uma sociedade em cujo seio o conflito social é cada vez mais enfrentado por padrões e consensos flexíveis e contextualmente estabelecidos. ${ }^{91}$ O afastamento de princípios gerais e regras formais e a aproximação de uma equidade contextualmente deter-

91 Ver, por exemplo, UNGER, R. M. Law in modern societ. toward a criticism of social theory. Nova York: Free Press; Londres: Collier Macmillan, 1976.; O'HAGAN, T. The End of Law? Oxford: Blackwell, 1984. minada pode refletir um fenômeno semelhante no desenvolvimento do pensamento e da prática jurídica internacional. Há razões suficientes para levar essa virada a sério - embora ela implique que os juristas repensem sua autoimagem profissional. Isso porque os assuntos relativos à justiça contextual não podem ser resolvidos por meio da aplicação de regras ou princípios prontos. Sua resolução requer aventurar-se por campos como a política, a causalidade social e econômica, que foram formalmente delimitados além do ponto em que o argumento jurídico deveria parar a fim de permanecer "legal”. Com certeza devemos permanecer incertos. As resoluções baseadas na aceitabilidade política não podem ser efetuadas com o tipo de certeza pós-iluminista que os juristas um dia acreditaram alcançar. E, no entanto, somente a manutenção de sua natureza é que impedirá que elas sejam usadas como apologias à tirania.

\section{REFERÊNCIAS}

ALLOT'T, P. Language, Method and the Nature of International Law. The British Yearbook of International Law, [S.l.], v. 45, p. 123-125, 1971.

ALLOTT, P. Power Sharing in the Law of the Sea. American Journal of International Law, [S.1.], v. 77, p. 1-30, 1983.

BEITZ, C. Political Theory and International Relations. Princeton: Princeton University Press, 1979.

BLECKMANN, A. Grundprobleme und Methoden des Völkerrechts. Freiburg: Alber, 1982.

BOYLE, Ideals and Things: International Legal Scholarship and the Prison-House of Language. Harvard Journal of International Law, [S.1.], v. 26, 1985.

BRAVO, L. Ferrari. La coutume internationale dans la pratique des etats. Recueil des Cours de l'Académie de droit international de la Haye, [S.1.], v. 192, p. 243, 1985.

C'EST à une conception fonctionnelle de pouvoir, à une conception sociale du droit que s'attache notre enseignement. Recueil des Cours de l'Académie de droit international de la Haye. v. 86, p. 451, 1954.

CARTY, A. The Decay of International Law?. Manchester: Manchester University Press, 1986.

CHEN, T. C. The International Law of Recognition. Londres: Stevens, 1951. 
CHENG, B. Custom, the future of general state practice in a divided world. In: MACDONALD, R. St. J.; JOHNSTON, D. M. (Ed.). The Structure and Process of International Law: essays in legal philosophy doctrine and theory. Haia: Martinus Nijhoff, 1983.

CRAWFORD, J. international law and foreign sovereigns, distinguishing immune transactions. The British Yearbook of International Law, [S.1.], v. 54, p. 114-118, 1983.

DICKINSON, E. D. The Equality of States in International Law. Cambridge: Harvard University Press, 1920.

EASTERN Greenland. PCIJ Rep, [s.L.], n. 53, p. 45-62.

FALK, R. The Interplay of Westphalia and Charter Conceptions of the International Legal Order. In: FALK, R.; BLACK, C. (Ed.). The Future of the International Legal Order. Princeton: Princeton University Press, 1969.

FINNIS, J. Natural Law and Natural Rights. Nova York: Clarendon Press, 1980.

FITZMAURICE, G. Vae Victis or Woe to the Negotiators!. American Journal of International Law, [S.1.], v. 65, p. 370-373, 1971.

GÜNTHER, H. ZurEnststehung von Völkergewohnheitsrecht. Berlim: Duncker \& Humblot, 1970.

HART, H. L. A. The Concept of Law. Oxford: Clarendon, 1961.

HEYDTE, A. F. Von der. Geburtstunde des souveränen Staates. Regensburg, 1952.

HINSLEY, F. H. Power and the Pursuit of Peace. Cambridge: Cambridge University Press, 1962.

HOBBES, T. Leviathan. Harmondsworth: Penguin Books, 1982.

ISLAND of Palmas case. Reports of International Arbitral Awards, [S.l.], v. 2, p. 839.

JELLINEK, G. Allgemeine Staatslehre. Berlim: Haring, 1925.

JENNINGS, R. The identification of international law. In: CHENG, B. (Ed.). International Law, Teaching and Practice. Londres: Stevens, 1982.

KATO, L. Recognition in international law: some thoughts on traditional theory, attitudes of and practice by african states. Indian Journal of International Law, [S.1.], vol. 10, p. 299-323, 1970.
KEARNEY, C. Sources of Law and the International Court of Justice. In: Gross, L. (Ed.). The Future of the International Court of Justice. Dobbs Ferry: Oceana Publications, 1976.

KELSEN, H. Das problem der souveränität und die theorie des völkerrechts. Tübingen: Mohr, 1920.

KELSEN, H. Principles of International Law. Nova York: Rinehart and Winston, 1966.

KENNEDY, D. The structure of blackstone's commentaries. Buffalo Law Review, [S.1.], v. 18, p. 205, 1979.

KOSKENNIEMI, M. From Apology to Utopia: the structure of international legal argument. Cambridge: Cambridge University Press, 2005.

KOSKENNIEMI, M. International Pollution in the Systems of International Law. Oikeustiede-Jurisprudentia, [S.l.], v. 17, p. 152-164, 1984.

KOSKENNIEMI, M. The normative force of habit: international custom and social theory. Finnish Yearbook of International Law, [S.1.], v. 1, p. 77, 1990.

KOSKENNIEMI, Martti. From Apology to Utopia. Cambridge: Cambridge University Press, 2005.

LAMMERS, J. 'Balancing the equities' international environmental law. Recueil des Cours de l'Académie de droit international de la Haye, [S.1.], p. 153-165, 1984.

LAUTERPACHT, H. International Law. Cambridge: Cambridge University Press, 1979.

LAUTERPACHT, H. Recognition in International Law. Cambridge: Cambridge University Press, 1948.

LAUTERPACHT, H. The Function of Law in the International Community. Oxford: Clarendon Press, 1933.

LAUTERPACHT, Hersch. Some Observations on the Prohibition of 'Non Liquet' and the Completeness of Law. Symbolae Verzijl, [S.l.], p. 196-221, 1958.

LEVINE, A. Liberal democracy: a critique of its theory. Nova York: Columbia University Press, 1981.

LOCK. Two Treatises on Government. Londres: Everyman's, 1984.

LOWE, A.V. The problem of extraterritorial jurisdiction: economic sovereignty and the search for a solution. International \& Comparative Law Quarterly, [S.1.], v. 34, p. 730, 1985. 
MACINTYRE, A. The Indispensability of Political Theory. In: MILLER, D.; SIEDENTOP, L. (Ed.) The Nature of Political Theory. New York: Clarendon Press, 1983.

MACLNTYRE, A. After Virtue: a study in moral theory. 2. ed. Notre Dame: University of Notre Dame Press, 1984.

MALI Frontier. ICJ Reports, Burkina Faso, n. 48, p. $567-$ 568, 1986.

MARTIN, A. L'estoppel en droit international public. Paris: Pedone, 1979.

MCDOUGAL, M. S. International law, power and policy: a contemporary perspective. Recueil des Cours de l'Académie de droit international de la Haye, [S.1.], v. 82, p. 133-259, 1953.

MENG, W. Völkerrechtliche zulässigkeit und grenzen der wirtschaftsverwaltungsrechtlichen hoheitsakte mit auslandswirkung. Zeitschrift für ausländisches öffentliches Recht und Völkerrecht, [S.1.], v. 44, p. 675-783, 1984.

MÜLLER, J. P. Vertrauenschutz, im Völkerrecht. Colônia: Heymann's, 1970.

NORTH Sea Continental Shelf. ICJ Reports, [S.l.], p. 2223, 1969.

O'HAGAN, T. The End of Law?. Oxford: Blackwell, 1984.

POLITIS, N. Les nouvelles tendances du droit international. Paris: Hachette, 1927.

POMERANCE, Michla. Self-determination in law and practic: the new doctrine in the united nations. Boston: Nijhoff, 1982.

POUND, R. Philosophical Theory and International Law. Bibliotheca Visseiana, [S.1.], v. 1, p. 1-90, 1923.

PRINCÍPIO 21 DA CONFERÊNCIA DA ONU SOBRE O MEIO AMBIENTE HUMANO, 1972, Estocolmo. UN Doc A/CONF48/14, 1972.

RATNER, S. R.; SLAUGHTER, A. M. The Methods of International Law. Washington: DC, ASIL, 2004.

ROSENTHAL, B. L'étude de l'cuvre de Myres Smith McDougal en matièredu droit international public. Paris: LGDJ, 1970.

ROUSSEAU, C. Principes de droit international public. Recueil des Cours de l'Académie de droit international de la Haye, [S.1.], v. 93, p. 394, 1958.
ROUSSEAU, J-J. The Social Contract. Tradução de Maurice Cranston. Harmondsworth: Penguin Books, 1986.

SCELLE, G. Précis de droit des gens: Principes et systématique I-II. Paris: Sirey, 1932.

SCHWARZENBERGER, G. The Forms of Sovereignty. Current Legal Problems, [S.1.], v. 10, p. 248, 1957.

SCHWARZENBERGER, G. The Inductive Approach to International Law. Londres: Stevens; Nova York: Oceana, 1965.

SCHWEBEL, S. Third report on the non-navigational uses of international watercourses. Yearbook of the International Law Commission, [S.1.], p. 75-100, 1982.

SEIDL-HOHENVELDEM, I. International economic law: general course on public international law. Recueil des Cours de l'Académie de droit international de la Haye, [S.I], v. 198, p. 54, 1986.

SØRENSEN, M. Les sources du droit international. Copenhague: Munskgaard, 1946.

STONE. Non-Liquet and the Function of Law in the International Community. The British Yearbook of International Law, [S.1.], v. 25, p. 124-16, 1958.

SUR, S. L'interpretation en droit international public. Paris: LGDJ, 1974.

TRIBUNAL ARBITRAL IRÃ-ESTADOS UNIDOS. Interpretation of the Algerian Declaration of 19th January 1981. ILR, v. 62, p. 599-600, 1982.

TRIEPEL, H. Völkerrecht und Landesrecht. Leipzig: Hirschfeld, 1899.

UNGA, Memorandum: on enhancing the role of international law. UN Doc. A/44/585. 1989.

UNGER, R. M. Knowledge and Politics. New York: The Free Press, 1975.

UNGER, R. M. Law in modern societ: toward a criticism of social theory. Nova York: Free Press; Londres: Collier Macmillan, 1976.

VERDROSS, Albert. Die Verfassung der Völkerrechtsgemeinschaft. Viena: Springer, 1926.

VERZIJL, J. H. W. International Law in Historical Perspective. Leiden: Sijthoff, 1968.

VINOGRADOFF, P. Historical Types of International Law. Leiden: Brill, 1920. 
VIRALLY, M. The Sources of International Law. In: SØRENSEN, M. (Ed.). Manual of Public International Law. Londres: Macmillan; Nova York: St Martin's Press, 1968.

WALZER, M. Just and Unjust Wars. Nova York: Harper and Collins, 1980.

WEIL, P. Towards Relative Normativity in International. Law American Journal of International Law, [S.1.], v. 77, p. 413-442, 1983.

WHEATON, H. Elements of International Law. Londres: Clarendon Press, 1936.
WIGHT, M. Western Values in International Relations. In: BUTTERFIELD, W. (Ed.). Diplomatic Investigations; Essays in the Theory of International Politics. Londres: Allen and Unwin, 1966.

Woolsey, T. D. Introduction to the Study of International Law: designed as an aid in teaching and in historical studies. 5. ed. Londres: Searle and Rivington, 1879.

ZOLLER, E. La bonne foi en droit international public. Paris: Pedone, 1977. 
Para publicar na Revista de Direito Internacional, acesse o endereço eletrônico www.rdi.uniceub.br ou www.brazilianjournal.org.

Observe as normas de publicação, para facilitar e agilizar o trabalho de edição. 